1983

\title{
Survey, Testing and Assessment of Cultural Resources in Portions of Willacy County Drainage District No. 1, Willacy County, Texas
}

Patricia A. Mercado-Allinger

Follow this and additional works at: https://scholarworks.sfasu.edu/ita

Part of the American Material Culture Commons, Archaeological Anthropology Commons, Environmental Studies Commons, Other American Studies Commons, Other Arts and Humanities Commons, Other History of Art, Architecture, and Archaeology Commons, and the United States History Commons

Tell us how this article helped you.

This Article is brought to you for free and open access by the Center for Regional Heritage Research at SFA ScholarWorks. It has been accepted for inclusion in Index of Texas Archaeology: Open Access Gray Literature from the Lone Star State by an authorized editor of SFA ScholarWorks. For more information, please contact cdsscholarworks@sfasu.edu. 
Survey, Testing and Assessment of Cultural Resources in Portions of Willacy County Drainage District No. 1, Willacy County, Texas

\section{Creative Commons License}

\section{(c) (1) \&}

This work is licensed under a Creative Commons Attribution-NonCommercial 4.0 International License 


\section{SURVEY, TESTING and ASSESSMENT of CULTURAL RESOURCES in PORTIONS of WILLACY COUNTY DRAINAGE DISTRICT NO. 1, WILLACY COUNTY, TEXAS}

by

Patricia A. Mercado-Allinger

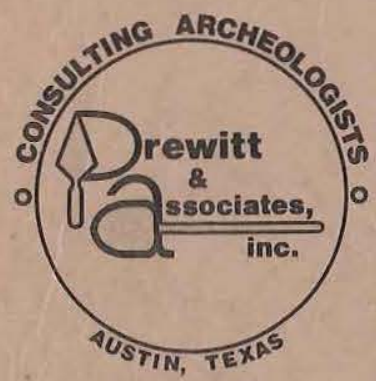

REPORTS OF INVESTIGATIONS, NUMBER 20 
SURVEY, TESTING AND ASSESSMENT OF CULTURAL RESOURCES IN PORTIONS OF WILLACY COUNTY DRAINAGE DISTRICT NO. 1, WILLACY COUNTY, TEXAS

by

Patricia A. Mercado-Allinger

PRINCIPAL INVESTIGATOR: Elton R. Prewitt

REPORTS OF INVESTIGATIONS NUMBER 20

Prewitt and Associates, Inc. Consulting Archeologists Austin, Texas

February 1983

State of Texas Antiquities Permit Nos. 321 and 328 
This two-part report is submitted to the Willacy County Drainage District No. 1, Lyford, Texas in partial fulfillment of letters of agreement dated July 12, 1982 and October 14, 1982. Al1 work reported in Part I of this report conforms to the provisions of state of Texas Antiquities Permit No. 321 and in Part II to that of State of Texas Antiquities Permit No. 328, issued by the Texas Antiquities Committee, Austin, Texas. 
ABSTRACT ............................... vi

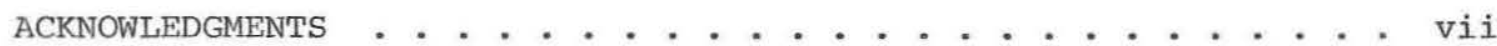

PART I: SURVEY AND ASSESSMENT OF CULTURAL RESOURCES IN PORTIONS OF WILIACY COUNTY DRAINAGE DISTRICT NO. 1 , WILLACY COUNTY, TEXAS . . . . . . . . . . 1

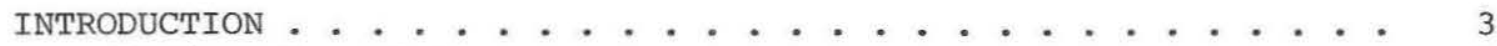

Project Description . . . . . . . . . . . . 3

Environmental setting............. 4

ARCHEOLOGICAL BACKGROUND . . . . . . . . . . . . . . . . . 4

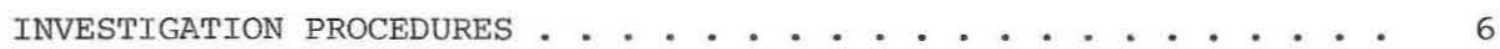

Survey Methods ................ . 7

Identification of Resources . . . . . . . . . 7

SURVEY RESULTS ........................... 8

Site Descriptions . . . . . . . . . . . 10

Isolated Finds . . . . . . . . . . . . 18

ARTIFACT DESCRIPTIONS . . . . . . . . . . . . . . . 29

Prehistoric Specimens... . . . . . . . . . 29

Historic Specimens ............. . . 39

CONCLUSIONS AND INTERPRETATIONS .................... 43

ASSESSMENTS AND RECOMMENDATIONS .................. . . 44

PART II: ARCHEOLOGICAL TESTING AND ASSESSMENT

OF SITE 41WY84, WILLACY COUNTY, TEXAS . . . . . . . 47

INTRODUCTION . . . . . . . . . . . . . . . . . . . 49

Project Description . . . . . . . . . . . . 49

RESEARCH DESIGN . . . . . . . . . . . . . . . . . . 49

Methodology .................. 50

SITE DESCRIPTION . . . . . . . . . . . . . . . . . 54

Stratigraphic Information .. . . . . . . . . 58

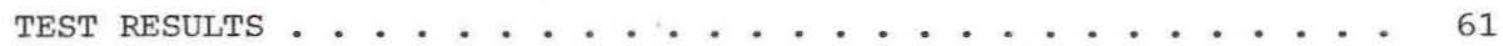

Specimen Descriptions .............. . 68

Specimen Distributions . . . . . . . . . . 72

Discussion and Summary . . . . . . . . . . . 73

Comparative Analysis . . . . . . . . . . . . 74 
REFERENCES CITED .

LIST OF FIGURES

1. Project location map ............... 5

2. Relationships of known cultural resources to relict channel systems and associated surface depressions, western project area . . . . . . . . . . . . . . 9

3. Relationships of known cultural resources to relict channel systems and associated surface depressions, eastern project area . . . . . . . . . . . 11

4. Artifact illustrations, knapped stone . . . . . . . 37

5. Artifact illustrations, pecked, ground and battered cobble .............. 41

6. Photographs of site 41 WY84 ............ 53

7. Site map, 41WY84 ............... 55

8. Test area schematic, site 41 WY84 . . . . . . . . . 57

9. Generalized cross sections, site 41 WY84 . . . . . . . 59

10. Site assemblage summary, 41 WY84 . . . . . . . . . 61 
1. Site distributions by environmental zone . . . . . . . . . 8

2. Summary of observed major specimen groupings, sites and isolated finds . . . . . . . . . . . . . 26

3. Provenience of prehistoric specimens, sites and isolated finds . . . . . . . . . . . . . 30

4. Provenience of collected historic specimens, sites and isolated finds . . . . . . . . . . . . . . 42

5. Summary of assessments by environmental zone . . • • • • • 43

6. Excavation information (1x1-m units) . . . . . . . . . 56

7. 41WY84: survey assemblage . . . . . . . . . . . . . 62

8. 41WY84: $20 \times 20-m$ surface collection units, provenience data . . . . . . . . . . . . . . 63

9. 41WY84: 1x1-m excavation units, provenience data . . • . . 64

10. Occurrence of terrestrial snails (in grams), site 41 WY84. . . 70

11. 41WY84: clay lump/ball physical characteristics • • • • . • 71

12. Site 41WY84: specimen distributions . . . . . . . . . . . 73

13. Comparative analysis; sites 41 WY $71,41 W Y 72$ and 41 WY 84 . . . 75 
Two archeological projects were undertaken in the fall of 1982 by Prewitt and Associates, Inc. Both projects were authorized by the Willacy County Drainage District No. 1.

The first investigation was an archeological survey to locate, record and assess previously unknown cultural resources which potentially could be affected by proposed drainage ditch development (Main Floodway Channel) in the central county area. Field inspections of this proposed alignment detected 24 archeological sites. Fourteen of these recorded sites are classified as isolated finds which are presumed to be prehistoric. The remaining ten resources are classified as sites, six containing prehistoric materials and four attributed to the recent (post-1900) historic past. Five of the prehistoric sites, 41WY84, 41WY86, 41WY89, 41WY90 and 41WY9l, were assessed initially as having high information yield potential, and testing was considered warranted prior to the construction of the Main Floodway Channel to more fully assess the potential eligibility of these sites for nomination to the National Register of Historic Places.

This recommendation for testing prompted the second project which involved test excavations at site 4lWY84. Site 4 IWY84 was selected from the five prehistoric sites for testing to better assess the nature and condition of these resources. It is concluded from the data recovered that site 4 lWY84 contains thinly dispersed cultural materials in a highly disturbed context and therefore does not warrant nomination to the National Register of Historic Places. On the basis of these testing results, archeological clearance for the proposed Willacy County Drainage District No. 1 Main Floodway Channel is recommended. 
The completion of the projects reported here was possible through the aid of several individuals. Of primary importance was the cooperation of the Willacy County Drainage District No. 1 of Lyford and its District Manager, Mr. Jim Riggan, and the engineering firm of Melden and Hunt, Inc., Edinburg. Thanks also are extended to all the landowners involved with the Main Floodway Channel. Mr. Floyd Rhodes was particularly cooperative by allowing testing of site 4lwY84, which is on his property.

Both field crews were provided with housing and hospitality by $\mathrm{Mr}$. and Mrs. "Tex" Foster of Raymondville, Texas.

A number of Prewitt and Associates, Inc. personnel contributed their efforts as well. The survey fieldwork was accomplished by the author and Assistant Archeologist, Vance O. Langley. Mr. Langley's familiarity with the area and its cultural resources proved invaluable. Testing of site 41 WY8 4 was undertaken with the capable assistance of Liz Day, Ron Holan and Jerri McLerran. Patricia A. Mercado-Allinger served as Project Archeologist for both projects and prepared this report.

Cartography was provided by Sandra Hannum Price and Kerza A. Prewitt. Linda Battles-Herron illustrated the artifacts, while administrative assistance and typing of the report was contributed by Linda Nance Foster and Cris Emmons.

The Principal Investigator for both projects, Elton R. Prewitt, assisted in editing and contributed the airphoto analysis. The historic ceramics were identified by Kerza A. Prewitt, and faunal identifications were made by Bonnie Yates. Laboratory processing was undertaken by the author with the assistance of Martin Salinas. 

PART I

SURVEY AND ASSESSMENT OF CULTURAL RESOURCES IN PORTIONS OF WILLACY COUNTY DRAINAGE DISTRICT NO. 1; WILLACY COUNTY, TEXAS 


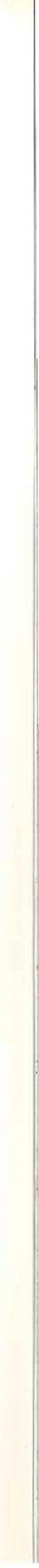


A cultural resources survey and assessment was conducted by Prewitt and Associates, Inc. along a proposed drainage ditch alignment in willacy County under terms of a letter of agreement with the willacy County Drainage District No. 1, Lyford, Texas. Fieldwork included inspection of those areas to be affected by drainage construction along the proposed 14.5 mile Willacy Drainage District No. 1 Main Floodway Channel. All investigations and survey results herein reported comply with the provisions of Permit No. 321 issued by the Texas Antiquities Committee to the Willacy County Drainage District 1.

Fieldwork was initiated on August 24, 1982 and was completed August 28, 1982. A two-person crew conducted these investigations with Patricia A. Mercado-Allinger serving as Project Archeologist and Vance O. Langley as Assistant Archeologist. The Principal Investigator was Elton R. Prewitt.

The current project is located in the same general area previously described by Day et al. (1981) and Mallouf et al. (1977). Day et al. (1981) reports surveys and assessments of the Hidalgo Drainage District Main Floodway alignment and various lateral ditches near the present project area. Therefore, background information which has been previously reported will only receive brief reference here; to facilitate discussion, the same terminology developed in these earlier reports has been incorporated.

\section{PROJECT DESCRIPTION}

The Willacy Country Drainage District No. I Main Floodway Channel is located north of the Arroyo Colorado in the northern edge of the Rio Grande delta plain. Its eastern limit is in central Willacy county. From this point, the alignment extends westward toward the HidalgoWillacy county line and passes between the towns of Raymondville and Lyford (Fig. 1).

No natural drainage occurs in this portion of the Rio Grande delta plain. This lack of drainage combined with the flat character of the landscape, contributes to periodic and prolonged episodes of flooding. As the main form of land use in the region is agriculture, the flooding problem is being addressed with a proposal which includes a complex of drainage systems under the jurisdiction of the Willacy County Drainage District No. 1. This plan involves improvements to existing agricultural earthen drainage ditches as well as the excavation of additional channels. The Willacy County Drainage District No. 1 Main Floodway Channel is a part of this proposed system.

Since the predictive sample survey conducted by Mallouf et al. (1977) and the reconnaissance of the Hidalgo County Drainage District Main Floodway Channel (Day et al. 1981) both report potentially significant cultural resources in the same general area, it was highly likely 
that other, unknown cultural materials would be impacted by further drainage development. The purpose of the current project was to determine, through field inspection, if cultural resources are present in the proposed channel development route.

\section{ENVIRONMENTAL SETTING}

Willacy County comprises a part of the Rio Grande delta plain in southern Texas. This area is included in the Matamoran district of the Tamaulipan biotic province (Blair 1950:102-105). Climate for this province is characterized as semiarid and megathermal with an average 61.65 $\mathrm{cm}$ annual rainfall which historically supported at least 61 species of mammals, 2 land turtles, 3 urodeles and 19 species of anurans (Blair 1950:102-105). Land clearing for agricultural purposes has eliminated the native brushland in the current project area. Day (1981:6-8) has compiled a list of biota observed in eastern willacy County which will not be repeated here.

The deltaic plain has a flat to slightly undulating surface topography. Elevations increase slowly westward from the Gulf shoreline. Only the late Pleistocene Beaumont Formation is exposed in the current project area. A thin veneer of surface sediments overlie the Beaumont Formation and are interlaced with relict interdistributary channel remnants and their associated eolian depressions (Mallouf et al. 1977:13).

In their predictive sampling survey, Mallouf et al. delineated seven environmental zones in Willacy County (1977:102-109). The proposed alignment of the Willacy County Drainage District No. 1 Main Floodway Channel alignment crosses two of these--Environmental Zones II and IV. Environmental Zone II is present only in the western limits of the project area near the Willacy-Hidalgo county line. Zone II, designated as Lasara Loess, is relatively flat and lacks natural rock or gravel outcrops (Mallouf et al. 1977:104). Environmental Zone IV, the Raymondville Alluvial Plain, also has a flat character and has no exposed rock or gravel resources (Mallouf et al. 1977:106), and comprises the majority of the project area. Neither zone has any natural drainage and both are susceptible to periodic flooding. Observed land use in these two zones is highly dependent upon agriculture. The project alignment includes one very small area north and east of Lyford which could not be considered agricultural.

\section{ARCHEOIOGICAL BACKGROUND}

A thorough review of past archeological research in the region is provided in Mallouf et al. (1977). The interested reader is directed to this reference for information on historic, ethnohistoric and prehistoric investigation undertaken before 1975 in the south Texas counties of Brooks, Cameron, Hidalgo, Jim Hogg, Kenedy, Starr, Zapata and willacy. Of note is Prewitt (1974), wherein a useful site situation 


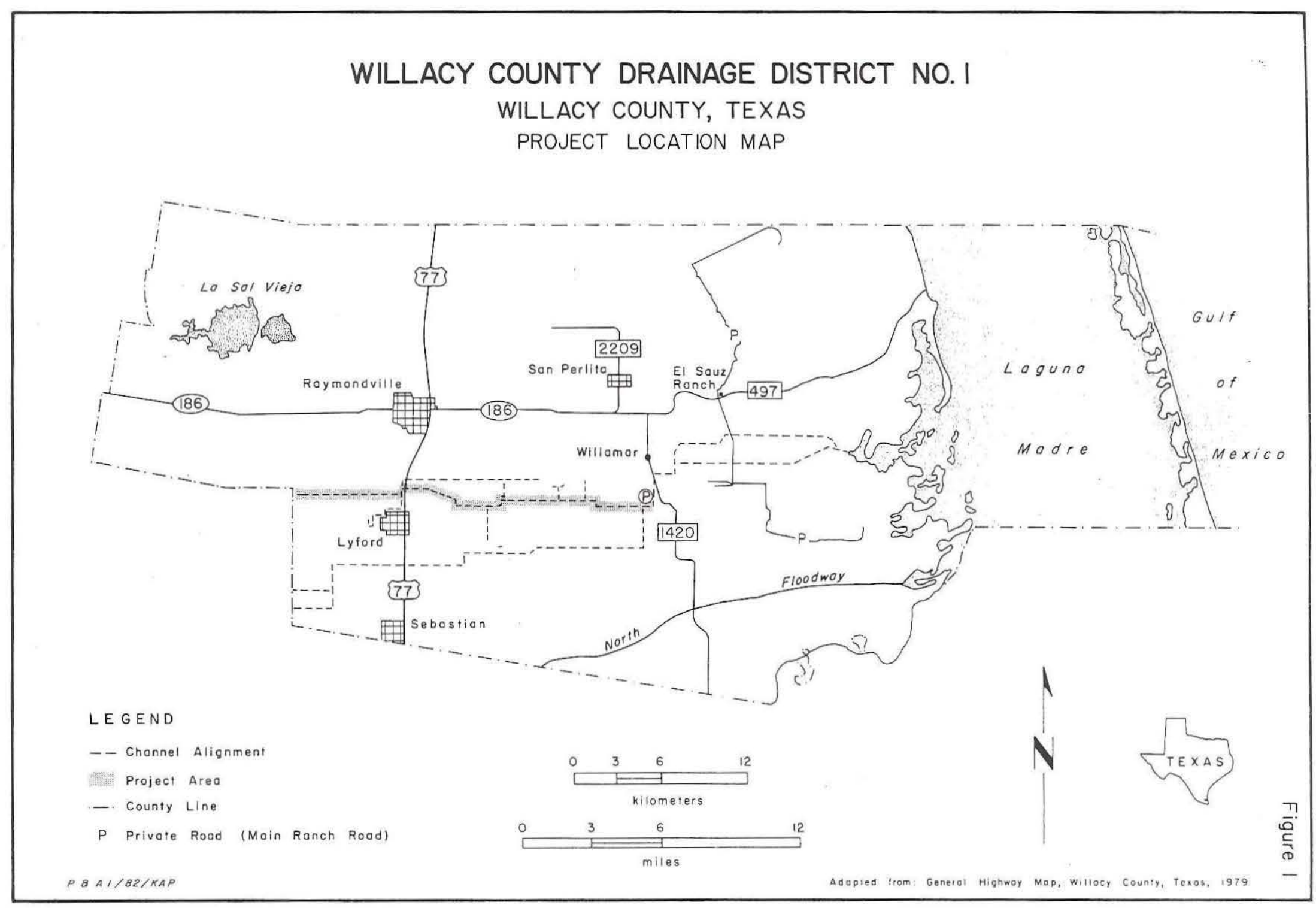


typology was developed on the basis of a survey in Cameron County and review of the A.E. Anderson collection.

Since 1975, a predictive sampling research project was conducted which stressed the significant interrelationships that environmental and geological characteristics have with the cultural resources in portions of Hidalgo and Willacy counties (Mallouf et al. 1977). Day et al. (1981) reported another cultural resource survey accompanied with limited testing in the two counties: this survey was guided by a predictive site location model using terminology and test implications developed in Mallouf et al. (1977). The most recent work in Willacy County involved testing of two prehistoric sites, 41WY71 and 4lWY72, in eastern Willacy County (Day 1981).

\section{INVESTIGATION PROCEDURES}

The current project followed closely the predictive model and investigative methodology defined in Day et al. (1981:26-31). It also incorporated additional airphoto analysis accomplished prior to field work. The airphotos used for this analysis are high altitude stereoscopic color aerial photographs taken of willacy County by the National Aeronautics and Space Administration (NASA) Mission 220 in 1972 with an approximate scale of 1:62 500. These airphotos were examined by using a stereoscopic viewer to identify surface features not shown on United States Geological Survey (USGS) 7.5' topographic sheets. In this manner, depressions and relict distributary channel scars were identified in and adjacent to the project alignment. These features were then plotted on the appropriate USGS $7.5^{\circ}$ sheets to be used in the field.

Briefly, the predictive model developed for this portion of the Rio Grande deltaic plain assumes a hunting-gathering adaptation by the aboriginal inhabitants on the basis of assembled prehistoric data (Mallouf et al. 1977:198). Such a lifeway is reliant upon the procurement of a variety of natural resources, particularly those associated with supplies of fresh water. Climatic conditions and the physical characteristics of the deltaic plain have important implications for this model. Each of these factors contribute to alternating periods of severe flooding and aridity for the area. Thus, aboriginal populations would probably have sought out higher elevations (such as those provided by natural levees along relict channel scars) during wetter seasons. Relict channel depressions likely contained potable water in drier times. The availability of other exploitable resources is expected to have been influenced by these conditions. Aboriginal settlement of the region is therefore anticipated to have involved a patterning of temporary and semi-permanent camps and resource exploitation localities dependent upon the availability of resources.

As stated earlier, the Willacy County Drainage District No. I Main Floodway Channel alignment txaverses portions of two environmental zones 
(II and IV). Geomorphic features identified for these two zones are limited to relict distributary channel scars and associated depressions. These features are considered to have high potential for containing archeological sites.

\section{SURVEY METHODS}

The current project represents a continuation of earlier surveys and assessments reported in Day et al. (1981). The research orientation was to locate, record and provide initial assessment of cultural resources encountered during the pedestrian inspection of the project area. Determination of potential impacts posed by proposed drainage development was the ultimate goal of this work.

Unlike the previous surveys, this project area included no unmodified land. The majority of the project alignment included cultivated fields, many of which were devoid of any vegetation at the time of inspection. Surface visibility therefore varied from good ( 75 percent) to excellent (100 percent) for much of the project area. The exceptions to this general statement were certain of the existing drainage ditches which support moderate to thick grass covers and a $4.6 \mathrm{~km}(3.7 \mathrm{mi})$ stretch immediately east of the sample 3 quadrant investigated by Mallouf et al. (1977:118-123). The area east of Sample 3 supports densely planted cotton crops which affords very limited surface visibility. The existing drainage ditch which extends through this same 4.6 $\mathrm{km}$ area was thickly covered with grass. In the areas where surface visibility was good to high (75-100 percent), the method of investigation generally involved two zigzagged sweeps, using the proposed alignment as a center line. Each sweep covered approximately $100 \mathrm{~m}$, providing an average coverage of $200 \mathrm{~m}$. In the more densely vegetated area, the strategy was modified. In the area containing growing crops, the survey procedure was to follow along alternate cultivated furrows to the desired $200 \mathrm{~m}$ width. Where drainage ditches existed, both cutbanks and the associated spoilage mound were intensively searched.

\section{IDENTIFICATION OF RESOURCES}

Archeological research in this area has established that prehistoric deposits contain a paucity of cultural materials. Common indicators are lithic tools, fired clay lumps and faunal remains such as bone and freshwater or marine shells. Combinations of these indicators detected within a $100 \mathrm{~m}$ surface diameter (or less) defines a prehistoric site (Day et al. 1981:34). Fired clay lumps in prehistoric context indicate hearth features. However, similar clay lumps may also be produced by historic field clearing and burning. Therefore, the presence of clay lumps does not necessarily establish the presence of a prehistoric site.

Historic sites commonly contain glass, metal, ceramics and structural remains. 
Several isolated finds were also noted during the current project. An isolated find is defined here as a solitary specimen or a concentration of homogeneous materials. Single lithic artifacts, clay lumps and bone fragments (or concentrations) were recorded as isolated finds. The latter two categories have questionable cultural associations.

Both archeological sites and isolated finds were recorded using State of Texas site data forms. Locations were plotted on USGS topographic sheets, and permanent trinomial designations have been assigned by the Texas Archeological Research Laboratory (TARL), The University of Texas at Austin. Since the entire project area was located in Willacy County, Texas, all numerical designations are prefaced with 41WY. Surface collections were limited to either diagnostic specimens or representative materials. Curation of these collections has been arranged with TARL.

Lastly, all cultural resource identifications were made solely on the basis of surface inspections. At no time were subsurface probes excavated.

\section{SURVEY RESULTS}

Twenty-four cultural resources locations were recorded by this investigation. More specifically, six are classified as prehistoric sites, four are historic sites and fourteen are isolated finds (Figs. 2 and 3 ).

Cultural resources were encountered in both of the defined environmental zones that occur in the project area. Distributions of these resources are given in Table 1.

TABLE 1

SITE DISTRIBUTIONS BY ENVIRONMENTAL ZONE

\begin{tabular}{lccc}
\hline & \multicolumn{2}{c}{ Environmental Zones } & \\
Temporal Affiliation & II & IV & Totals \\
\hline Prehistoric & - & 6 & 6 \\
Historic & 1 & 3 & 4 \\
Isolated Finds & $\frac{2}{3}$ & $\frac{12}{21}$ & $\frac{14}{24}$ \\
TOTALS & & & \\
\hline
\end{tabular}




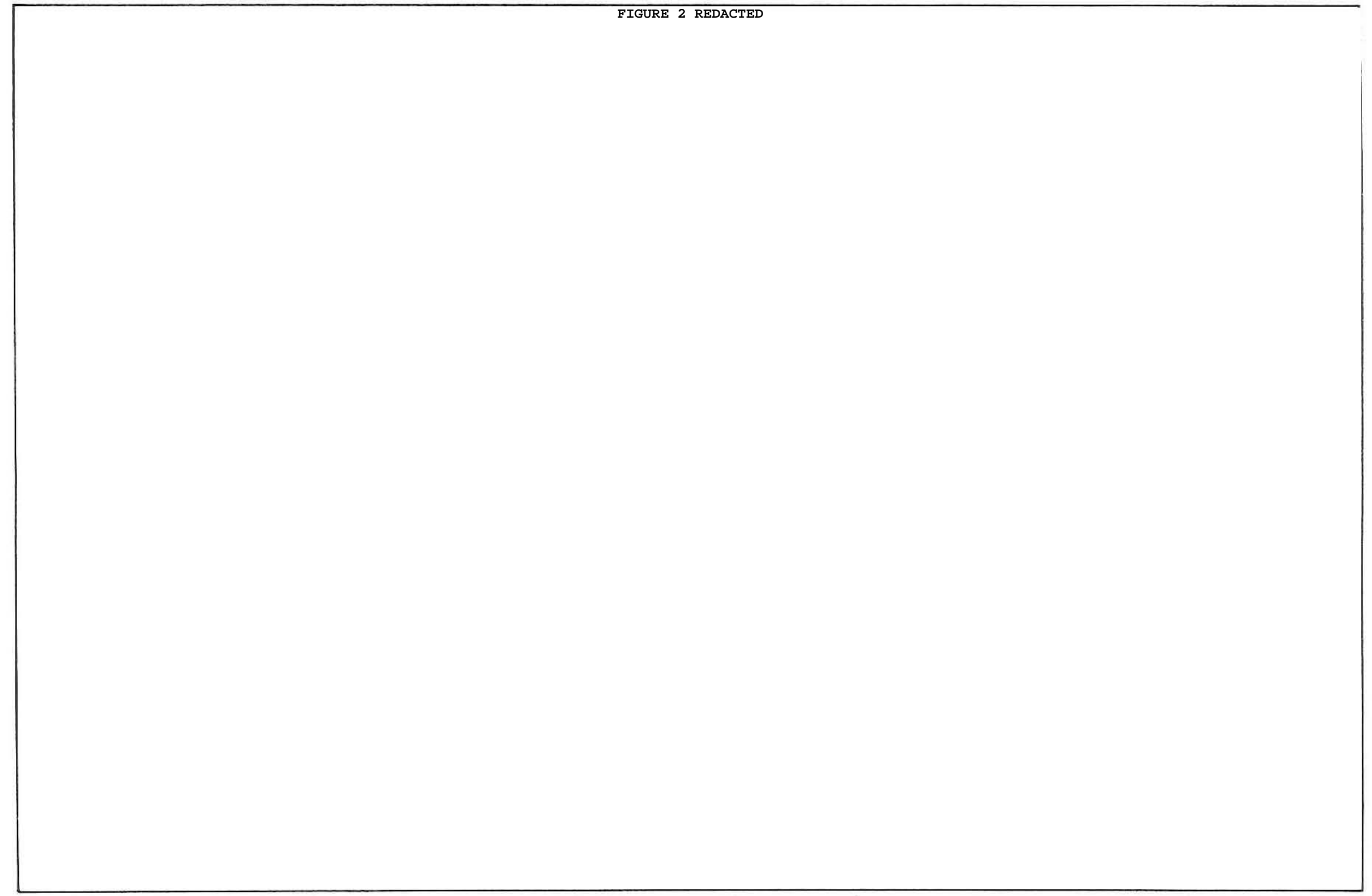




\section{Collections: 1 decalcomania sherd; 4 glass fragments.}

Discussion: The USGS topographic sheet indicates that a windmill was present in this location in the recent past. Inspection produced no evidence of structures or food debris.

Assessment: The site is a recent (twentieth century) historic trash scatter. Present information indicates that this deposit exhibits a low information yield potential.

Recommendations: Further work is felt not to be scientifically productive at this time.

41 WY 83

Elevation: Approximately $6 \mathrm{~m}$ above $\mathrm{ms}$

Environmental Zone: IV

Map Reference: USGS Willamar 7.5' (1956, revised 1970)

Location: $\begin{aligned} & \text { TEXT } \\ & \text { REDA } \\ & \text { CTED }\end{aligned}$

Description: The deposit was noted in the southern exposure of an existing drainage ditch. There is a visible rise immediately to the north.

Horizontal Extent: $5 \mathrm{~m} \mathrm{~N}-\mathrm{S}$ by $10 \mathrm{~m} \mathrm{E}-\mathrm{W}$

Vertical Extent: $1.5-1.6 \mathrm{~cm}$ below the present surface

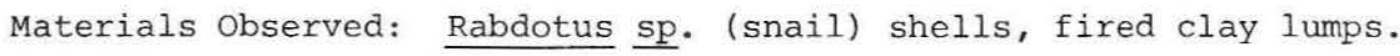

Collections: None.

Discussion: This is a probable prehistoric campsite deposit which has been exposed by the present drainage ditch. An isolated find, 41 WY93 (a Matamoros point), is located on the spoil mound $10 \mathrm{~m}$ to the south.

Assessment: Undetermined information yield potential.

Recommendations: Further work is felt not to be scientifically productive at this time. 
Elevation: Approximately $7.3 \mathrm{~m}$ above $\mathrm{msl}$

Environmental Zone: IV

Map Reference: USGS San Perlita South 7.5' (1956, revised 1970)

Location:

TEXT REDACTED

Description: The site was found in both a plowed field and in the cutbank of an adjacent drainage ditch. Vegetation grows along this ditch causing visibility to vary from 30 to 100 percent, and includes johnsongrass, bermudagrass, mesquite and sunflowers.

Horizontal Extent: Approximately $70 \mathrm{~m}^{2}$

Vertical Extent: Approximately $1 \mathrm{~m}$ below the present surface.

Materials Observed: 2 pieces of lithic debitage, fired clay lumps, numerous bone fragments.

Collections: 2 pieces of lithic debitage, 2 fired clay lumps, 7 bone fragments.

Discussion: The debitage includes one rhyolite chip and one sili-cious limestone bifacial thinning flake. The bone specimens include a Bison sp. fragment with a cut edge, and six unidentified mammal fragments. Some of the mammal bones appear to be charred.

Assessment: The site appears to be a prehistoric camp or resource exploitation site. Undisturbed deposits may be present below the plowzone. Information yield potential is considered high at this site.

Recommendations: Subsurface testing may be warranted to determine the presence of potentially significant materials prior to further drainage ditch development.

\section{WY85}

Elevation: Approximately $12 \mathrm{~m}$ above msl

Environmental Zone: II

Map Reference: USGS Raymondville 7.5' (1956, revised 1970)

Location: TEXT

CTED 
Description: The site is situated in a plowed field from which cotton has recently been harvested. Three relict channel scars are located to the east, west and south. No vegetation was present at the time of inspection.

Horizontal Extent: $100 \mathrm{~m} \mathrm{~N}-\mathrm{S}$ by $130 \mathrm{~m} \mathrm{E}-\mathrm{W}$

Vertical Extent: Undetermined.

Materials Observed: Ceramic sherds (whiteware), glass fragments (clear, purple), charred bone fragments, 1 brick fragment, 1 copper pipe fitting collar (diameter: $3 \mathrm{in}$ ).

Collections: None.

Discussion: The glass observed was bottle glass with no markings. Overall, the deposit is a thin scatter which has been displaced by repeated plowing.

Assessment: The site appears to be a twentieth century trash scatter, possibly associated with an occupation. Present information indicates that this deposit has a low information yield potential.

Recommendations: Further work is felt not to be scientifically productive at this time.

\section{WY86}

Elevation: Approximately $10.5 \mathrm{~m}$ above msl

Environmental Zone: IV

Map Reference: USGS Raymondville 7.5' (1956, revised 1970)

Location: TEXT REDACTED

d.

Description: The site is a thin deposit found in an intensively cultivated field. At the time of inspection, the field was fallow and covered with a moderately dense cover of forbs. Several relict channel scars have been noted in the area.

Horizontal Extent: $10 \mathrm{~m}^{2}$

Vertical Extent: Undetermined.

Materials Observed: 1 fragment of marine shell (scallop), 1 long bone element.

Collections: All materials observed were collected. 
Discussion: The collected bone specimen has been identified as a goat/sheep (Capra/Ovis) metacarpal of probable recent origin. This bone may not be associated with the marine shell fragment.

Assessment: This is a possible prehistoric aboriginal camp or resource exploitation site. Information yield potential is high.

Recommendations: The presence of marine shell indicates the possibility of potentially significant deposits. Subsurface testing prior to channel development may be warranted at this site to determine eligibility to the National Register of Historic Places.

\section{WY87}

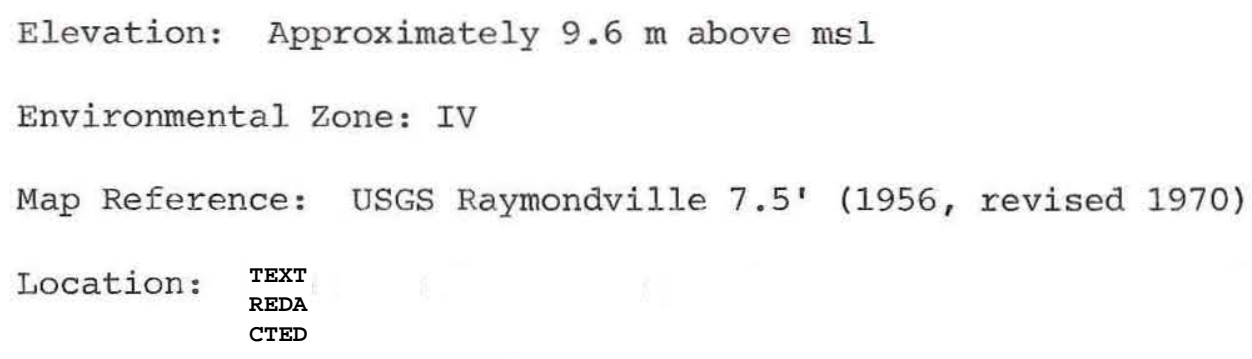

Description: An existing drainage ditch runs north-south along the eastern site limit. A thick growth of bermudagrass covers this ditch, while the site proper is in a plowed flat field. North of the site area, a cotton crop was growing at the time of inspection. A relict depression is also present to the north.

Horizontal Extent: $25 \mathrm{~m} \mathrm{~N}-\mathrm{S}$ by $35 \mathrm{~m} \mathrm{E}-\mathrm{W}$

Vertical Extent: Undetermined.

Material Observed: Ceramic sherds (earthenware, stoneware, decalcomania), glass bottle fragments (clear, purple), rusted metal bolts and brick fragments.

Collections: 3 ceramic sherds, 2 glass fragments.

Discussion: The collected ceramic sherds were identified as stoneware and earthenware. The collected glass included one bottle neck and rim, and one handle. All observed materials were attributable to the twentieth century.

Assessment: The USGS map shows structures were present at this location in the recent past. This historic trash scatter probably indicates the remains of these structures which, judging from the nature of observed materials, were probably twentieth-century occupations. Present information indicates a low information yield potential at this site. 
Recommendations: Further work is felt not to be scientifically productive at this time.

41 WY 88

Elevation: Approximately $3.8 \mathrm{~m}$ above $\mathrm{msl}$

Environmental Zone: IV

Map Reference: USGS Raymondville 7.5' (1956, revised 1970)

Location:

TEXT REDACTED

e.

Description: The site is in a plowed field which contains three parallel northwest-southeast trending relict drainages.

Horizontal Extent: $30 \mathrm{~m} \mathrm{~N}-\mathrm{S}$ by $45 \mathrm{~m} \mathrm{E}-\mathrm{W}$

Vertical Extent: Undetermined.

Materials Observed: Ceramic sherds (decalcomania), glass bottle fragments (amber, clear, milk, green), brick and concrete pieces, cartridge cases and a cow-sized vertebra fragment.

Collections: None.

Discussion: All of the observed materials were attributable to the twentieth century and represent common household and hardware items.

Assessment: This trash scatter is probably what remains of an historic (twentieth century) occupation. The present information indicates a low information yield potential at this sité.

Recommendations: Further work is felt not to be scientifically productive at this time.

\section{WY89}

Elevation: Approximately $9 \mathrm{~m}$ above $\mathrm{msl}$

Environmental Zone: IV

Map Reference: USGS Raymondville 7.5' (1956, revised 1970)

Location: TEXT

CTED 
Description: This deposit is in a cultivated field which was recently harvested, allowing 100 percent surface visibility. A large depression is located over $100 \mathrm{~m}$ to the west of the site. The surface of the site slopes gradually to the southwest.

Horizontal Extent: $85 \mathrm{~m} \mathrm{~N}-\mathrm{S}$ by $54 \mathrm{~m} \mathrm{E}-\mathrm{W}$

Vertical Extent: Undetermined.

Materials Observed: One modified split cobble and three clay lumps were observed on the plowed field while a possible clay lump hearth feature was noted in the western bank of an existing drainage ditch immediately to the east of the major site area.

Collections: One modified split cobble.

Discussion: A local farmer indicated that massive disturbance of this particular field has included land leveling, vegetation clearing and filling. The site area has therefore undergone extensive displacement.

Assessment: This deposit is a prehistoric camp or resource exploitation site which may still contain undisturbed, intact materials below the plowzone.

Recommendations: Subsurface testing may be warranted at this location prior to further drainage development to establish the presence or absence of potentially significant deposits.

\section{$\underline{41 W Y 90}$}

Elevation: Approximately $8.4 \mathrm{~m}$ above msl.

Environmental Zone: IV

Map Reference: USGS San Perlita South 7.5' (1956, revised 1970)

Location: $\begin{array}{ll}\text { TEXT } \\ \text { REDA } \\ \text { CTED }\end{array}$

Description: A relict channel levee is present immediately to the east. No natural vegetation remains in the vicinity. Visibility of the surface varies from 25 to 100 percent.

Horizontal Extent: $160 \mathrm{~m} \mathrm{~N}-\mathrm{S}$ by $80 \mathrm{~m} \mathrm{E}-\mathrm{W}$

Vertical Extent: Undetermined.

Materials Observed: 3 thick-walled bone fragments, 1 chert unifacial blade and several fired clay lumps. 
Collections: 1 chert unifacial blade, 1 bone fragment.

Discussion: The blade specimen is a side scraper, and the bone is an unidentified mammal fragment.

Assessment: This deposit is a prehistoric camp or resource exploitation site which may contain undisturbed deposits below the plowzone.

Recommendations: Subsurface testing may be warranted prior to further channel development to determine whether potentially significant cultural resources are present at this site.

41WY91

Elevation: Approximately $9 \mathrm{~m}$ above msl

Environmental Zone: IV

Map Reference: USGS San Perlita South 7.5' (1956, revised 1970)

Location:

TEXT REDACTED

Description: The deposit is in a plowed field containing a slight rise overlooking a sand-filled relict channel scar depression. Surface visibility was excellent (90 to 100 percent) at the time of inspection.

Horizontal Extent: $150 \mathrm{~m}$ NW-SE by $100 \mathrm{~m} \mathrm{NE}-\mathrm{SW}$

Vertical Extent: Undetermined.

Materials observed: One battered cobble and numerous fired clay lumps.

Collections: One battered cobble.

Discussion: The collected specimen is a silicified limestone cobble which exhibits battering along its edges, and pecking and grinding on the undamaged surface.

Assessment: Intact deposits may be present below the plowzone.

Recommendations: Subsurface testing may be warranted at this site to establish the presence or absence of potentially significant materials.

ISOLATED FINDS

$\underline{41 W Y 92}$

Elevation: Approximately $6.6 \mathrm{~m}$ above $\mathrm{msl}$ 
Environmental Zone: IV

Map Reference: USGS Willamar 7.5' (1956, revised 1970)

Location: $\quad$ TEXT

TED

Description: This isolated find was recovered in a barren plowed field. A slight rise is visible to the north.

Horizontal Extent: Undetermined.

Vertical Extent: Undetermined.

Materials Observed: One Bison sp. proximal femur fragment.

Collections: Same as observed.

Assessment: The specimen does not appear to be culturally modified and may not be a cultural phenomenon.

Recommendations: Further work is felt not to be scientifically productive at this time.

\section{$\underline{41 W Y 93}$}

Elevation: Approximately $6 \mathrm{~m}$ above $\mathrm{ms}$

Environmental Zone: IV

Map Reference: USGS Willamar 7.5' (1956, revised 1970)

Location: An

TEXT REDACTED

Description: The find was on the surface of a spoil mound. Plowed fields surround the area and a drainage ditch is immediately to the north.

Horizontal Extent: Undetermined.

Vertical Extent: Undertermined.

Materials Observed: One triangular projectile point.

Collections: Same as observed.

Assessment: The characteristics of the point suggests that it is a Matamoros type. 
Recommendations: Further work is felt not to be scientifically productive at this time.

41 WY94

Elevation: Approximately $12 \mathrm{~m}$ above ms 1

Environmental Zone: II

Map Reference: USGS Raymondville 7.5' (1956, revised 1970)

Location: $\begin{aligned} & \text { TEXT } \\ & \text { REDA } \\ & \text { CTED }\end{aligned}$

Description: Plowed flat fields surround the find. Aerial photos indicate a relict channel scar at this location.

Horizontal Extent: Undetermined.

Vertical Extent: Undetermined.

Materials Observed: One medial projectile point fragment.

Collections: Same as observed. type.

Assessment: The point is a triangular specimen of undetermined

Recommendations: Further work is felt not to be scientifically productive at this time.

\section{WY95}

Elevation: Approximately $12 \mathrm{~m}$ above msl

Environmental Zone: II

Map Reference: USGS Raymondville 7.5' (1956, revised 1970)

Location:

TEXT REDACTED

Description: Flat fields are cultivated in the area, eliminating all natural vegetation. The find is located between two relict channel scars in a dirt road.

Horizontal Extent: Undetermined.

Vertical Extent: Undetermined. 
Materials observed: One small fragment of a medium-sized mammal long bone, $1.5 \mathrm{~cm}$ in length and slightly mineralized.

Collections: None.

Assessment: The bone observed did not have any cultural modification and may not have been culturally deposited.

Recommendations: Further work is felt not to be scientifically productive at this time.

\section{WY96}

Elevation: Approximately $9 \mathrm{~m}$ above $\mathrm{ms} 1$

Environmental Zone: IV

Map Reference: USGS Raymondville 7.5' (1956, revised 1970)

Location: $\begin{aligned} & \text { TEXT } \\ & \text { REDA } \\ & \text { CTED }\end{aligned}$

Description: The find was situated in a cultivated field south of a relict depression. None of the natural vegetation remains in this field which currently supports a milo maize crop.

Vertical Extent: Undetermined.

Horizontal Extent: Undertermined.

Materials Observed: One thick-walled bone fragment.

Collections: Same as observed.

Assessment: The bone could not be identified more precisely than as mammalian. No cultural modifications were noted on the bone, which may not have been culturally deposited.

Recommendations: Further work is felt not to be scientifically productive at this time.

$\underline{41 W Y 97}$

Elevation: Approximately $9 \mathrm{ft}$ above msl

Environmental Zone: IV

Map Reference: USGS Raymondville 7.5' (1956, revised 1970) 
Location: $\begin{aligned} & \text { TEXT } \\ & \text { REDA } \\ & \text { CTED }\end{aligned}$

Description: The find was recovered from a barren plowed field. A slight rise is visible immediately to the south.

Horizontal Extent: Undetermined.

Vertical Extent: Undetermined.

Materials Observed: One lithic specimen.

Collections: Same as observed.

Assessment: The specimen is a split cobble with possible modification of one edge.

Recommendations: Further work is felt not to be scientifically productive at this time.

\section{WY98}

Elevation: Approximately $9 \mathrm{~m}$ above msl

Environmental Zone: IV

Map Reference: USGS Raymondville 7.5' (1956, revised 1970)

Location: TEXT

CTED

Description: The find was encountered in an existing drainage ditch cutbank. Relict channels trend northwest-southeast in the area, and a slight rise is visible to the south. Visibility was good (75 percent) as a sparse cover of bermudagrass and sunflowers is growing on the bank.

Horizontal Extent: Undetermined.

Vertical Extent: Undetermined.

Materials Observed: Three fragments of antler.

Collections: Same as observed.

Assessment: The fragments were identified as antler and exhibit no recognizable cultural modification. These items may not have been culturally deposited. 
Recommendations: Further work is felt not to be scientifically productive at this time.

41 WY99

Elevation: Approximately $8.7 \mathrm{~m}$ above $\mathrm{msl}$

Environmental Zone: IV

Map Reference: USGS San Perlita South 7.5' (1956, revised 1970)

Location:

TEXT REDACTED

Description: The find was located in an existing drainage ditch. Bermudagrass and sunflowers are growing along the ditch. A relict channel is present to the south.

Horizontal Extent: Undetermined.

Vertical Extent: Undetermined.

Materials Observed: 1 fired clay lump.

Collections: None.

Assessment: Although the clay lump may not have been culturally derived, its location in a drainage cutbank indicates that it may have been buried prior to drainage construction.

Recommendations: Further work is felt not to be scientifically productive at this time.

\section{WY100}

Elevation: Approximately $8.7 \mathrm{~m}$ above $\mathrm{msl}$

Environmental Zone: IV

Map Reference: USGS San Perlita South 7.5' (1956, revised 1970)

$\begin{array}{ll}\text { Locations: } & \text { TEXT } \\ \text { REDA } \\ \text { CTED }\end{array}$

Description: The find was noted in an existing drainage ditch where bermudagrass and sunflowers are growing. A relict channel is present to the south. 
Horizontal Extent: Undetermined.

Vertical Extent: Undetermined.

Materials Observed: 1 fired clay lump.

Collections: None.

Assessment: Although this clay lump may not have been culturally derived, its location indicates it may have been buried prior to drainage construction.

Recommendations: Further work is felt not to be scientifically productive at this time.

\section{WY101}

Elevation: Approximately $6.6 \mathrm{~m}$ above $\mathrm{ms}$

Environmental Zone: IV

Map Reference: USGS San Perlita South 7.5' (1956, revised 1970)

Location: TEXT

CTED

Description: The find was noted on top of a spoil mound devoid of vegetation and located northeast of a northwest-southeast-trending relict channel. A depression was visible approximately $100 \mathrm{~m}$ to the southwest. The spoil mound crest is barren, but on the slopes bermudagrass and sunflowers form a thick cover. The surrounding fields support cultivated crops.

Horizontal Extent: $1 \mathrm{~m}^{2}$.

Vertical Extent: Surface.

Materials Observed: A small concentration of large mammal bone fragments.

Collections: None.

Assessment: The observed bones were unidentifiable as to species or element. No cultural modification was detected on these items which are in displaced context. The original context could not be determined.

Recommendations: Further work is felt not to be scientifically productive at this time. 


\section{WY102}

Elevation: Approximately $6.6 \mathrm{~m}$ above msl

Environmental Zone: IV

Map Reference: USGS San Perlita South 7.5' (1956, revised 1970)

Location:

TEXT REDACTED

Description: The find is on the same spoil mound on which 41WY101 was recorded. Again, vegetation is lacking on the mound crest, but is thick along its slopes and is comprised of sunflowers and bermudagrass. A relict channel depression is to the southwest.

Horizontal Extent: $1 \mathrm{~m}^{2}$.

Vertical Extent: Surface.

Material Observed: Small concentration of medium-sized mammal bone fragments.

Collections: None.

Assessment: The bone was unidentifiable as to element or species and showed no signs of cultural modification. The deposit, as it was observed, is in a highly disturbed context. Its origin could not be determined.

Recommendations: Further work is felt not to be scientifically productive at this time.

\section{WY103}

Elevation: Approximately $7.5 \mathrm{~m}$ above msl

Environmental Zone: IV

Map Reference: USGS San Perlita South 7.5' (1956, revised 1970)

Location: $\underset{\substack{\text { TEXT } \\ \text { REDAC } \\ \text { TED }}}{\text { Lech }}$

Description: The find was recorded on top of a spoil mound immediately west of a relict channel depression. Bermudagrass covers the mound slope rather thickly but is sparse in the vicinity of the find.

Horizontal Extent: $5 \mathrm{~m}^{2}+$.

Vertical Extent: Surface. 
TABLE 2

SUMMARY OF OBSERVED MAJOR SPECIMEN GROUPINGS, SITES AND ISOLATED FINDS

Artifact Category

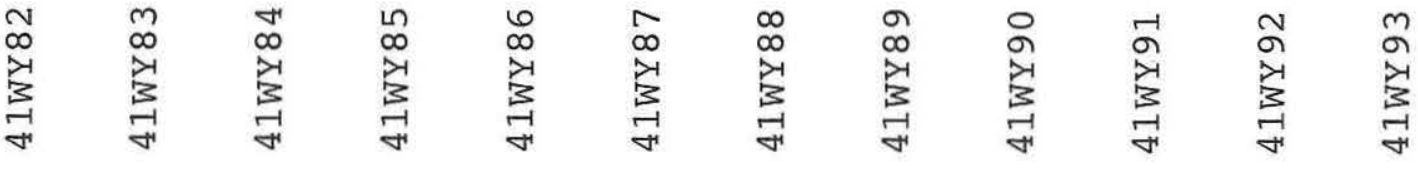

PREHISTORIC SPECIMENS

Debitage

Unifaces

Projectile Points

Other Bifaces

Ground Pecked Stone

Fired Clay Lumps

Faunal Remains

Modified

Unmodified

HISTORIC SPECIMENS

Ceramics

Glass

Metal

Brick/Concrete

Faunal Remains

$\begin{array}{llll}- & - & x & - \\ - & - & - & - \\ - & - & - & - \\ - & - & - & - \\ - & - & - & - \\ - & x & x & - \\ - & x & x & - \\ - & - & x & - \\ - & x & x & -\end{array}$

$\begin{array}{ll}- & - \\ - & - \\ - & - \\ - & - \\ - & - \\ - & - \\ x & - \\ - & - \\ x & -\end{array}$

$\mathrm{X}=$ presence $;-=\mathrm{absence}$ 
Table 2, continued

Artifact Category

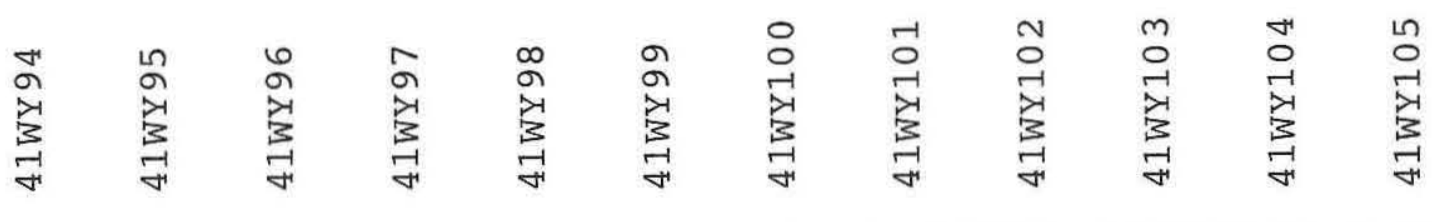

PREHISTORIC SPECIMENS

Debitage

Unifaces

Projectile Points

Other Bifaces

Ground Pecked Stone

N Fired Clay Lumps

Modified

Unmodified

HISTORIC SPECIMENS

\section{Ceramics}

Glass

Metal

Brick/Concrete

Faunal Remains

$\begin{array}{lll}- & - & - \\ - & - & - \\ x & - & - \\ - & - & - \\ - & - & - \\ - & - & - \\ - & x & x \\ - & - & - \\ - & x & x\end{array}$

$\mathrm{X}=$ presence $;-$ = absence . 
Materials Observed: Concentration of thick, flat bone (100+ piece) fragments.

Collections: 6 flat fragments and 1 round fragment of bone.

Assessment: One of the flat specimens and the round specimen were identified as marine turtle plastron and rib fragments, respectively. The other material is turtle shell of undetermined species. As the find is in displaced context, cultural associations could not be established at the time of inspection.

Recommendations: Further work is felt not to be scientifically productive at this time.

\section{WY104}

Elevation: Approximately $9.5 \mathrm{~m}$ above msl

Environmental Zone: IV

Map Reference: USGS San Perlita South 7.5' (1956, revised 1970)

Locations :

TEXT REDACTED

Description: The find was located on the southern cutbank of an existing drainage ditch located immediately west of a relict channel depression. Bermudagrass is growing on this slope, and surface visibility varies from 0 to 90 percent.

Horizontal Extent: Undetermined.

Vertical Extent: Undetermined.

Materials Observed: 1 fired clay lump.

Collections: None.

Assessment: The isolated nature of this find makes cultural associations questionable. However, its location in a drainage cut suggests that the specimen may have been buried and subsequently exposed by ditch construction.

Recommendations: Further work is felt not to be scientifically productive at this time.

\section{$\underline{41 W Y 105}$}

Elevation: Approximately $6.9 \mathrm{~m}$ above msl 
Environmental Zone: IV

Map Reference: USGS San Perlita South 7.5' (1956, revised 1970)

Location: This find is located $3 \mathrm{~km}$ south of FM 490, southwest of Willamar and north of an existing drainage ditch.

Description:

TEXT REDACTED

Horizontal Extent: Undetermined.

Vertical Extent: Undetermined.

Materials Observed: 2 fired clay lumps.

Collections: None.

Assessment: No cultural associations can be definitely made with this find at this time.

Recommendations: Further work is felt not to be scientifically productive at this time.

\section{ARTIFACT DESCRIPTIONS}

Limited surface collections were made at two historic sites ( 41 WY82 and 41WY87) as well as at five prehistoric sites (41WY84, 41WY86, 41 WY $89,41 W Y 90$ and 41WY91). Seven of the isolated finds were also collected (41WY92, 41WY93, 41WY94, 41WY96, 41WY97, 41WY98 and 41WY103). Descriptions of these specimen are provided below according to prehistoric or historic affiliations; provenience is given by site. Artifact terminology and presentation is compatible with Day et al. (1981).

PREHISTORIC SPECIMENS

Specimens identified as prehistoric included three analytical categories: lithic artifacts, fired clay lumps and faunal remains. Identifications are made using the most general descriptive divisions, progressing when possible to more precise categories using functional terms, established tool types and faunal taxonomy. Provenience of the artifacts is summarized in Table 3 .

Knapped Stone

All artifacts which were manufactured by the removal of flakes, whether in the resulting production of a tool or representing chipping debris is included in this category. 


\section{TABLE 3}

PROVENIENCE OF PREHISTORIC SPECIMENS: SITES AND ISOLATED FINDS

\begin{tabular}{|c|c|c|c|c|c|c|}
\hline \multirow[b]{3}{*}{ Specimen Category } & \multirow[b]{2}{*}{ 41WY84 } & \multirow{3}{*}{$\begin{array}{c}41 \text { WY } 86 \\
0-1\end{array}$} & \multicolumn{2}{|l|}{ Sites } & \multirow{3}{*}{$\begin{array}{c}41 W Y 91 \\
0-1\end{array}$} & \multirow{3}{*}{ 41WY92 } \\
\hline & & & 41WY89 & $41 W Y 90$ & & \\
\hline & $0-1 \quad 0-2$ & & $0-1$ & $0-1$ & & \\
\hline
\end{tabular}

KNAPPED STONE

Projectile Points

Matamoros type

Unidentified triangular

Bifaces

Gouge

Modified pebble/cobble

Unifaces

Side scraper

Debitage

Flake

Unmodified

Thinning

Platform present

Unprepared

Prepared

Decortication

Primary

Secondary

Tertiary

$\begin{array}{lll}- & - & - \\ - & - & - \\ - & - & - \\ - & - & - \\ - & - & - \\ - & - & - \\ - & - & - \\ - & - & - \\ 1 & 1 & - \\ 1 & - & - \\ 1 & - & - \\ - & 1 & - \\ 1 & 1 & - \\ 1 & - & - \\ - & 1 & - \\ - & - & - \\ - & - & - \\ 1 & - & - \\ - & 1 & -\end{array}$

-
-
1
1
-
-
-
-
-
-
-
-
-
-
-
-

-
-
-
-
-
1
1
-
-
-
-
-
-
-
-

-

-

-

-

$-$

$-$

$-$

- 
Table 3, continued

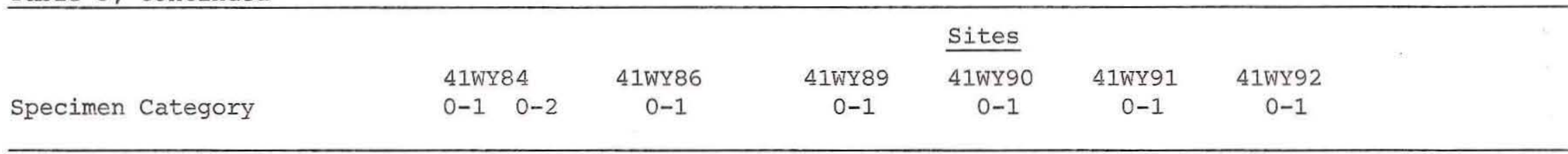

GROUND PECKED STONE

Multipurpose tool

FAUNAL REMAINS

Antler

Bone fragments

Bison sp.

Capra/Ovis

Unidentified mammal

Charred

Marine turtle

Plastron

Rib

Unidentified turtle

Shell

Marine shell

FIRED CLAY LUMPS

TOTAL SPECIMENS:

$\begin{array}{lll}- & - & - \\ - & - & - \\ 4 & 3 & 1 \\ - & 1 & - \\ - & - & 1 \\ 4 & 2 & - \\ - & 2 & - \\ - & - & - \\ - & - & - \\ - & - & - \\ - & - & - \\ - & - & 1 \\ 2 & - & - \\ 7 & 4 & 2\end{array}$

1

$-$

1

$-$

-

1

$\begin{array}{ll}- & - \\ - & 1 \\ - & 1 \\ - & - \\ - & - \\ - & - \\ - & - \\ - & - \\ - & - \\ - & - \\ - & - \\ - & - \\ 1 & -\end{array}$


Table 3, continued

Isolated Finds

Specimen Category

\begin{tabular}{|c|c|c|c|c|c|c|c|c|c|c|c|c|}
\hline & & & & & & & 임 & 검 & $\stackrel{N}{N}$ & $m$ & ஏ' & เก \\
\hline$m$ & $\nabla$ & เก & 6 & $r$ & $\infty$ & の & 0 & 0 & 0 & 0 & 0 & 0 \\
\hline a & の & の & の & の & の & の & $\Gamma$ & $\Gamma$ & - & ${ }^{1}$ & 다 & - \\
\hline$\vec{\lambda}$ & $\forall-1$ & $>-1$ & $>1$ & $\not 1$ & $\not 1$ & $\geq 1$ & $\not 1$ & $\vec{r}$ & $>1$ & $\overrightarrow{1}$ & $\mathrm{Z}^{-1}$ & $\overrightarrow{1}$ \\
\hline 3 & 3 & 3 & $\frac{3}{1}$ & 3 & $\frac{3}{1-1}$ & $\frac{3}{1}$ & 交 & $\underset{1}{3}$ & $\frac{3}{1}$ & $\frac{3}{1-1}$ & $\frac{3}{4}$ & $\frac{3}{1-1}$ \\
\hline & $\forall$ & $\nabla$ & 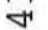 & $\forall$ & $\nabla$ & 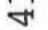 & 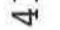 & $\nabla$ & $\sigma^{\prime}$ & $\nabla$ & $\forall$ & \\
\hline
\end{tabular}

KNAPPED STONE

Projectile points

Matamoros type

Unidentified triangular

Bifaces

Gouge

$\stackrel{w}{N}$

Modified pebble/cobble

Unifaces

Side scraper

Debitage

Flake

Unmodified

Modified

Platform present

Unprepared

Prepared

Decortication

Primary

Secondary

Tertiary

GROUND PECKED STONE

Multipurpose tool 
Table 3, continued

\section{Isolated Finds}

\begin{tabular}{|c|c|c|c|c|c|c|c|c|c|c|c|c|c|}
\hline Specimen Category & 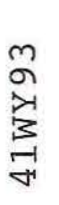 & 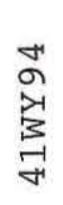 & 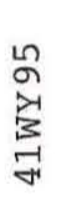 & 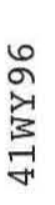 & \begin{tabular}{l}
$\hat{a}$ \\
\multirow{1}{*}{} \\
3 \\
\multirow{r}{*}{}
\end{tabular} & 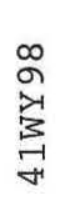 & 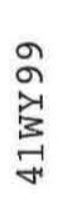 & 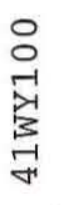 & 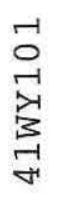 & 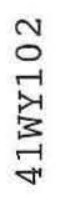 & 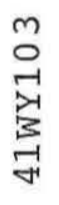 & 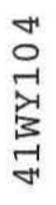 & 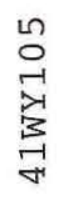 \\
\hline \multicolumn{14}{|l|}{ FAUNAL REMAINS } \\
\hline Antler & - & - & - & - & - & 3 & - & - & - & - & - & - & - \\
\hline Bone fragments & - & - & - & 1 & - & - & - & - & - & - & 7 & - & - \\
\hline Bison sp. & - & - & - & - & - & - & - & - & - & - & - & - & - \\
\hline$\overline{\text { Capra/Ovis }}$ & - & - & - & - & - & - & - & - & - & - & - & - & - \\
\hline Unidentified mammal & - & - & - & 1 & - & - & - & - & - & - & - & - & - \\
\hline Charred & - & - & - & - & - & - & - & - & - & - & - & - & - \\
\hline Marine turtle & - & - & - & - & - & - & - & - & - & - & 2 & - & - \\
\hline Plastron & - & - & - & - & - & - & - & - & - & - & 1 & - & - \\
\hline Rib & - & - & - & - & - & - & - & - & - & - & 1 & - & - \\
\hline Unidentified turtle & - & - & - & - & - & - & - & - & - & - & 5 & - & - \\
\hline SHELL & - & - & - & - & - & - & - & - & - & - & - & - & - \\
\hline Marine shell & - & - & - & - & - & - & - & - & - & - & - & - & - \\
\hline FIRED CLAY LUMPS & - & - & - & - & - & - & - & - & - & - & - & - & - \\
\hline TOTAL SPECIMENS: & 1 & 1 & - & 1 & 1 & 3 & - & - & - & - & 7 & - & - \\
\hline
\end{tabular}


Debitage (2 specimens)

Only two debitage specimens were encountered during this project, both at site 41WY84:

\section{(1) Specimen 1}

Description: Triangular debitage flake with one straight lateral edge and one broken edge. The distal edge is convex. The platform exhibits cortex. No other modification was noted on the specimen.

Cross Section: Triangular.

Material: Banded rhyolite.

Dimensions: Length, $11.25 \mathrm{~mm}$; width, $5.05 \mathrm{~mm}$; thickness, 1.25

$\mathrm{mm}$.

\section{Provenience: 41 WY 84.}

\section{(2) Specimen 2 (Fig. 4a)}

Description: Discoidal bifacial thinning flake exhibiting a prepared (ground) platform and no cortex. The lateral edges are convex and the distal edge terminates in a step fracture.

$2.25 \mathrm{~mm}$.

Cross Section: Planoconvex.

Material: Silicified yellow limestone.

Dimensions: Length, $33.20 \mathrm{~mm}$; width, $31.25 \mathrm{~mm}$; thickness,

Provenience: 41 WY84.

\section{Unifaces}

Only one artifact exhibits unifacial modification. The specimen is described below:

Scraper (Fig. 4b)

Description: This is a thin side scraper with steeply beveled chipped lateral edges. One lateral edge is nearly straight, and the other is slightly concave.

Cross Section: Planoconvex.

Material: Light tan-gray chert.

$\mathrm{mm}$.

Dimensions: Length, $37.45 \mathrm{~mm}$; width, $8.40 \mathrm{~mm}$; thickness, 3.00 


\section{Provenience: $41 W Y 90$.}

\section{Bifaces}

The project collection contains four bifacial artifacts that includes modified pebbles (or small cobbles) and projectile points.

$\underline{\text { Modified Pebbles/Cobbles }}$

(1) Specimen 1 (Fig. 4c)

Description: This is a subcircular split pebble with two flake scars on its exterior face and interior evidence of battering present on the same edge, producing a concave bit. This bit does not appear to have much use-wear. The specimen conforms to Miscellaneous Biface Form 2 (Mallouf et al. 1977:180).

\section{Cross Section: Planoconvex.}

Material: Light pink rhyolitic porphyry. ness, $13.25 \mathrm{~mm}$.

Dimensions: Length, $37.00 \mathrm{~mm}$; width, $32.20 \mathrm{~mm}$; thickProvenience: 41WY97.

(2) Specimen 2 (Fig. 4d)

Description: This is a discoidal modified split cobble fragment with a bifacially knapped convex bit showing extensive wear.

Material: Dark charcoal gray igneous material (hornblende?) with a band of speckled gray chert impurity.

ness, $13.20 \mathrm{~mm}$.

Dimensions: Length, $51.25 \mathrm{~mm}$; width, $43.20 \mathrm{~mm}$; thickProvenience: 41 WY89.

\section{Projectile Points}

Two projectile points in isolated contexts were collected.

\section{(1) Specimen 1 (Fig. 4e)}

Description: This is a complete triangular point with convex edges and base which conforms to the Matamoros type (Bell 1958:46-47).

Cross Section: Lenticular.

Material: Dark charcoal gray igneous porphyry. 
Figure 4. Artifact illustrations, knapped stone.
a. Debitage; bifacial thinning flake (41WY84)
b. Uniface; blade side scraper (41WY90)
c. Biface; modified pebble (41WY97)
d. Biface; cobble gouge, showing dorsal and ventral faces (41WY89)
e. Projectile point; Matamoros type (41WY93)
f. Projectile point; untyped fragment (41WY94)

Artifacts shown at actual size. 
Figure 4
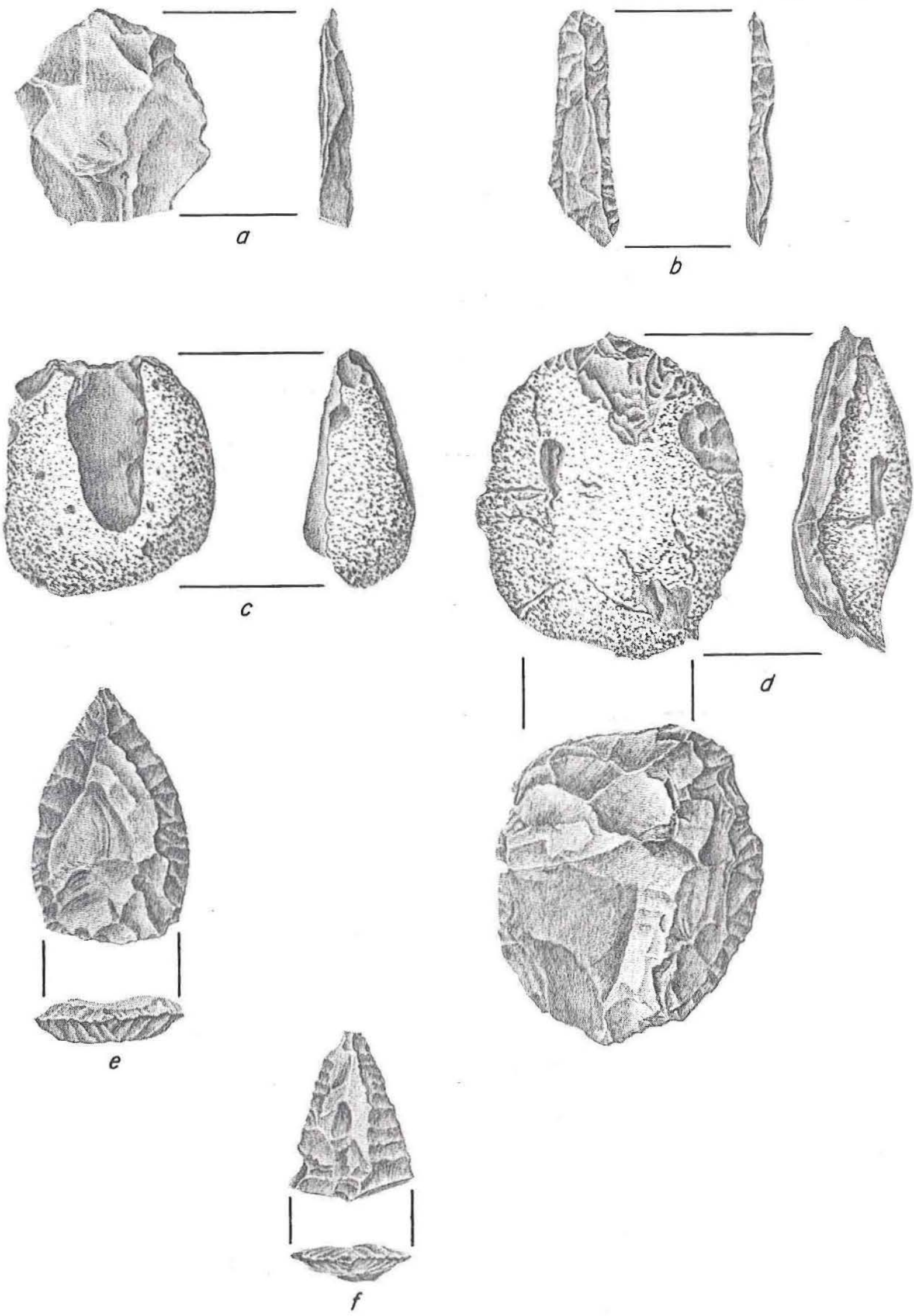
$\mathrm{mm}$.

Dimensions: Length, $40.3 \mathrm{~mm}$; width, $23.2 \mathrm{~mm}$; thickness, 4.2

Provenience: 41 WY93.

(2) Specimen 2 (Fig. 4f)

Description: This is a triangular medial point fragment with generally straight edges. One edge has a small notch. Type is undetermined.

$2.25 \mathrm{~mm}$.

\section{Cross Section: Planoconvex.}

Material: Tan chert with gray impurities.

Dimensions: Length, $25.05 \mathrm{~mm}$; width, $22.40 \mathrm{~mm}$; thickness,

Provenience: 41 WY93.

Multipurpose Stone Tool (Fig. 5)

A large cobble was collected which showed signs of grinding, battering and pecking.

Description: This is a large, subrounded cobble with battering damage evident along two edges. One face exhibits both pecking and grinding wear and is slightly concave. The other face has undergone extensive plow damage.

\section{Cross Section: Ovoid.}

Material: Yellow silicious limestone.

Dimensions: Length, $104.2 \mathrm{~mm}$; width, $89.0 \mathrm{~mm}$; thickness, $46.0 \mathrm{~mm}$.

Provenience: 41 WY103.

\section{$\underline{\text { Faunal Remains }}$}

A total of eighteen bone fragments, one marine shell and three antler fragments were recovered from 41WY84, 41WY86, 41WY90, 41WY92, 41WY96, 41WY98 and 41WY103. Only one bone specimen (41WY84,' Lot 0-2), possibly Bison sp., exhibits definite cultural modification in the form of a cut edge. Two additional mammalian bone fragments from the same site (41WY84) appear to have been charred. Otherwise, cultural associations of the recovered faunal remains is tenuous. Provenience of the remaining unmodified specimens is provided below:

41WY84: 4 bone fragments

41WY86: 1 goat/sheep metacarpal, 1 marine shell fragment 
41WY90: 1 large mammal bone fragment

41WY92: 1 Bison sp. proximal femur

41WY96: 1 large mammal bone fragment

41Wy98: 3 antler fragments

Fired Clay Lumps

Two specimens were recovered from site 41 WY84 (Lot 0-1).

HISTORIC SPECIMENS

The historic materials collected during the current project at sites 41 WY 82 and 41 WY 87 are believed to date to the present century, probably from 1930 to the present. None of the nine recovered specimens were found to be particularly diagnostic of significant time periods or events.

Only two categories of historic artifacts are represented in the survey collection; ceramic and glass. Brief descriptions of each are given below and are followed by a provenience summary table (Table 4).

Ceramics (3 specimens)

\section{Decorated Earthenware (2 specimens)}

One specimen is a red decalcomania (41WY82) body sherd. The other is a whiteware basal sherd with molded decoration (41WY87).

Decorated Stoneware (1 specimen)

This is a body sherd with interior cream glaze and an exterior red orange wash (41WY87).

Glass (6 specimens)

Clear (4 specimens)

Two bottle neck and rim fragments were recovered. One is from site 41WY82, has a collared rim, and shows slight patination. The specimen from 41 WY87 is a collar and ring form.

One bottle or jar base (4lWY82) has the letters "...glas" molded on its exterior. Lastly, one handle fragment (41WY87) was also collected. None of these items show any indication of manganese or selenite bleaching. 
Figure 5. Artifact illustrations; pecked, ground and battered cobble showing two faces (41WY91).

Artifact shown at actual size. 
Figure 5
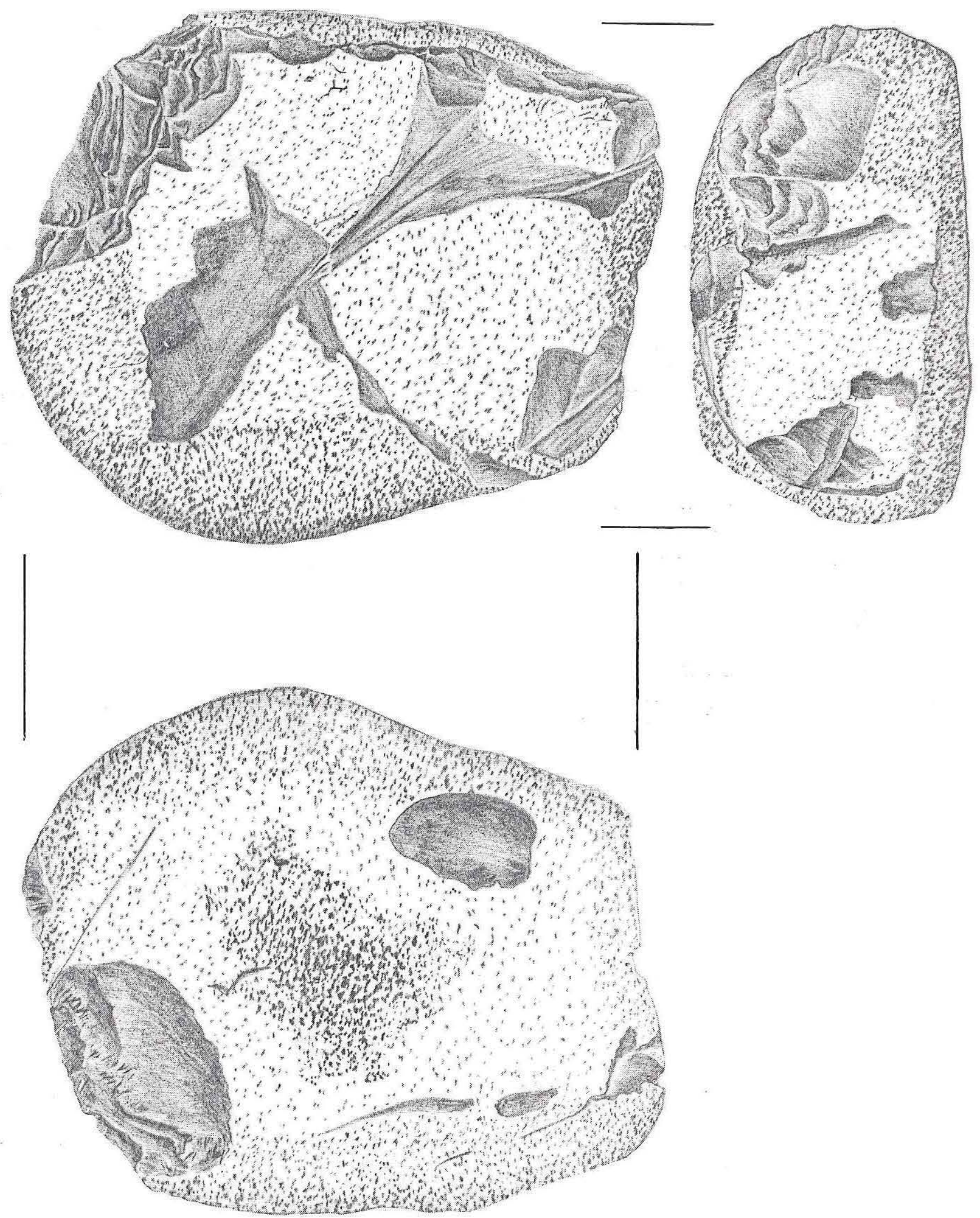
Blue (1 specimen)

One jar base fragment (41WY82) was recovered. Molded lettering on this specimen reads: "VAPORUB 52."

Green Opaque (1 specimen)

One molded body fragment was collected from site 41WY82. Selenite bleaching is evident on this specimen.

TABLE 4

PROVENIENCE OF COLLECTED HISTORIC SPECIMENS, SITES AND ISOLATED FINDS

$(\mathrm{n}=9)$

\begin{tabular}{|c|c|c|c|c|}
\hline Specimen Category & 41 WY82 & $41 W Y 85$ & $41 W Y 87$ & $41 W Y 88$ \\
\hline CERAMICS & 1 & - & 2 & - \\
\hline Decorated earthenware & & & & \\
\hline Decalcomania & 1 & - & - & - \\
\hline Molded decoration & - & - & 1 & - \\
\hline \multicolumn{5}{|l|}{ Decorated stoneware } \\
\hline \multicolumn{5}{|l|}{$\begin{array}{l}\text { Interior glaze, } \\
\text { exterior wash }\end{array}$} \\
\hline exterior wash & - & - & 1 & - \\
\hline GLASS & 4 & - & 2 & - \\
\hline \multicolumn{5}{|l|}{ Clear } \\
\hline Bottle/jar & 2 & - & 1 & - \\
\hline $\begin{array}{l}\text { Neck rim, collared } \\
\text { Neck rim, collar }\end{array}$ & 1 & - & - & - \\
\hline and ring & - & - & 1 & - \\
\hline Base, molded lettering & 1 & - & - & - \\
\hline Handle & - & - & 1 & - \\
\hline \multicolumn{5}{|l|}{ Blue } \\
\hline \multicolumn{5}{|l|}{ Bottle/jar, base with } \\
\hline \multicolumn{5}{|l|}{ Opaque green } \\
\hline \multicolumn{5}{|l|}{ Body sherd with } \\
\hline molded decoration & 1 & - & - & - \\
\hline TOTALS & 5 & - & 4 & - \\
\hline
\end{tabular}




\section{CONCLUSIONS AND INTERPRETATIONS}

The distribution of aboriginal sites along the Willacy County Drainage District No. 1 Main Floodway Channel is consistent with the predictive model across Environmental Zones II and IV. However, the summary of findings according to zone (Table 5) should be viewed with the project bias for Zone IV.

TABLE 5

SUMMARY OF ASSESSMENTS BY ENVIRONMENTAL ZONE

\begin{tabular}{|c|c|c|c|c|}
\hline $\begin{array}{l}\text { Environ- } \\
\text { mental } \\
\text { Zone }\end{array}$ & Site No. & $\begin{array}{l}\text { Temporal } \\
\text { Affiliation }\end{array}$ & $\begin{array}{l}\text { Assessment } \\
\text { of Potential }\end{array}$ & Recommendations \\
\hline \multirow[t]{3}{*}{ II } & 41WY85 & Historic & Low & No further work* \\
\hline & 41WY94 & Prehistoric & Low & No further work \\
\hline & 41WY95 & Prehistoric & Low & No further work \\
\hline \multirow[t]{21}{*}{ IV } & 41WY82 & Historic & LOW & No further work \\
\hline & $41 W Y 83$ & Prehistoric & Undetermined & No further work \\
\hline & 41WY84 & Prehistoric & High & Subsurface test \\
\hline & 41WY86 & Prehistoric & High & Subsurface test \\
\hline & $41 W Y 87$ & Historic & Low & No further work \\
\hline & 41WY88 & Historic & Low & No further work \\
\hline & $41 W Y 89$ & Prehistoric & High & Subsurface test \\
\hline & $41 W Y 90$ & Prehistoric & High & Subsurface test \\
\hline & 41WY91 & Prehistoric & High & Subsurface test \\
\hline & 41WY92 & Prehistoric & Low & No further work \\
\hline & $41 W Y 93$ & Prehistoric & Low & No further work \\
\hline & 41 WY96 & Prehistoric & Low & No further work \\
\hline & 41WY97 & Prehistoric & Low & No further work \\
\hline & 41WY98 & Prehistoric & Low & No further work \\
\hline & 41WY99 & Prehistoric & Low & No further work \\
\hline & 4IWY1.00 & Prehistoric & Low & No further work \\
\hline & 41WY101 & Prehistoric & Low & No further work \\
\hline & 41WY102 & Prehistoric & Low & No further work \\
\hline & 41WY103 & Prehistoric & Low & No further work \\
\hline & 41WY104 & Prehistoric & Low & No further work \\
\hline & 41WY105 & Prehistoric & Low & No further work \\
\hline
\end{tabular}

*No further work = Further work is felt not to be scientifically productive at this time.

Aboriginal sites continued to be found by these investigations in locations associated with relict distributary channel scars or nearby 
areas identified from airphoto analysis as low levees and eolian depressions. Inspection of existing drainage ditches also presented evidence for the possibility of additional subsurface cultural resources.

Surface materials which appear to be prehistoric in age were recorded at six sites, 41WY83, 41WY84, 41WY86, 41WY89, 41WY90 and 41WY91. The 14 isolated finds (41WY92 through 41WY105) have also been tentatively identified as prehistoric. More precise temporal assignments are not possible due to the small number of collected materials and the lack of a reliable cultural chronology or developmental construct for the region. The following interpretations however, are presented on the basis of observed prehistoric materials:

1. Lithic tool manufacturing and useage are indicated at sites and isolated finds.

2. Lithic resources were procured from distances of over $45 \mathrm{~km}$ (36 mi), suggesting wide ranging exploitation activities or trade.

3. The presence of fired clay lumps both in isolated and site deposit context suggest probable cooking/heating activities.

4. Terrestrial (medium to large mammal) and marine animal (turtle and shellfish) species may have been exploited prehistorically.

5. The sparse and dispersed nature of the recorded sites, which may have been a condition of original deposition, have been impacted by land clearing and cultivation.

Each of the historic sites contained materials attributable to post-1900 land use and are probably indicative of farming or ranching. The predictive model was a less effective locational tool for these resources.

\section{ASSESSMENTS AND RECOMMENDATIONS}

As stated earlier, the current project area involves no unmodified land. Modification has included the clearing of vegetation, surface leveling, cultivation and, in certain areas, the excavation of drainage ditches.

It was therefore difficult to make assessments of significance or recommendations for further research on the basis of observations made on these highly disturbed land surfaces. Nonetheless, determinations of anticipated information yield potential were attempted for each cultural resource recorded (Table 5). Resources were ranked according to high, low or undetermined information yield potentials.

Assessments of low or undetermined information yield potentials were made for all isolated finds, historic deposits and one site tentatively identified as a prehistoric camp. Isolated finds were assessed 
thusly due to their highly disturbed and isolated context or questionable cultural derivation. Historic sites were assessed as having low information potential on the basis of the recent (post-1900) materials found and the absence of structural features. Site 41 wy83 was designated as having undetermined potential because of a lack of demonstrable cultural material. Additional field investigations are therefore not considered to be scientifically productive at this time for those resources assessed as having low or undetermined information yield potential.

The possibility of undisturbed and buried deposits below the plowzone was considered for the remaining sites. Significant data could occur at these locations, which subsurface testing would establish. Testing may then be warranted before channel development along the proposed alignment. It is recommended that such action be considered to allow for proper assessment of eligibility to the National Register of Historic Places for those sites assessed as having high potential.

Undisturbed and buried cultural deposits may exist below the plowzone at these remaining sites. Consequently, significant archeological data may be expected at sites 41WY84, 41WY86, 41WY89, 41WY90 and 41WY91. However, to establish the integrity of the deposits and to demonstrate the actual information yield potential of these sites, subsurface testing is required. This testing should be done before additional construction of the drainages ditches is initiated, and should be of sufficient scope to allow a determination of eligibility for nomination to the National Register of Historic Places for each of the sites.

The lack of excavated prehistoric archeological sites in the general project area makes it difficult to predict what may be encountered within an excavated context, and even more difficult to anticipate the scope of testing needed to accurately assess the information yield potential of any specific site. In order to address these problems, a limited program of investigation is recommended. Rather than test all five of the sites which are felt to require more detailed assessments, it is suggested that only one site be selected for initial testing and that the testing be of sufficient scope to allow preliminary calculations of the density of cultural materials and the presence or absence of isolatable occupational zones or strata.

If this testing at one site yields positive data collection results, then all five sites should be considered as eligible for nomination to the National Register of Historic Places. In this case, the ditch should be rerouted to avoid the sites, or if this is not possible, then intensive controlled excavations should be undertaken to mitigate the loss of the sites.

However, if the testing yields negative results, then none of the sites would be considered eligible for nomination to the National Register. In this instance, no further archeological work would be required and construction could proceed with altering the expected route of the ditch. 
It is suggested that site 41 WY8 4 near the east end of the project area be selected for the testing program. Since construction is expected to begin at the east end of the project alignment and extend westward, this will allow sufficient time for adjustments to be made in the project routing or for site mitigation to be effected as may be necessary. 
, 
PART II

ARCHEOLOGICAL TESTING AND ASSESSMENT OF SITE 41WY84, WILLACY COUNTY, TEXAS 

INTRODUCTION

The test excavation of prehistoric site 4 IWY84 was undertaken by Prewitt and Associates, Inc. under terms of a letter of agreement with Willacy County Drainage District No. 1, Lyford, Texas. The testing results reported herein comply with the provisions of Permit No. 328 issued by the Texas Antiquities Committee to the Willacy County Drainage District No. 1 .

Field investigations required eight working days which were initiated on November 2, 1982 and completed on November 11, 1982. The field crew consisted of the Project Archeologist, Patricia A. MercadoAllinger, and three Archeological Assistants: Liz Day, Ron Holan and Jerri McLerran. Elton R. Prewitt served as Principal Investigator.

Site 41 WY84 was located and documented during the cultural resources survey and assessment of the proposed Main Floodway Channel Alignment reported in Part I of this report. Testing of site 41 WY 84 was proposed to more fully assess the potential eligibility for nomination to the National Register of Historic Places of one of the five prehistoric sites recorded within the alignment right-of-way. The paucity of excavated prehistoric archeological sites in the general project area makes difficult the assessment of a site's information yield potential on the basis of surface evidence. One local testing program reported by Day (1981) indicated that cultural material density was low while labor intensity requirements were high. It was felt, therefore, that test excavation of one prehistoric site would provide the data necessary for assessment purposes for all five sites.

Since envixonmental and archeological background information has already been provided in Part I of this report, it is not repeated here.

\section{PROJECT DESCRIPTION}

Site 41 WY8 4 is in Willacy County, Texas, southeast of the community of Willamar (Fig. 1, Part I). This site was recorded during the surface survey of the proposed Willacy County Drainage District No. 1 Main Floodway Channel, reported in Part I of this report. Site 41WY84 is situated near the eastern limit of this channel alignment which extends from central Willacy County westward toward the Willacy-Hidalgo county line, passing between the towns of Lyford and Raymondville.

\section{RESEARCH DESIGN}

The testing strategy followed at 41 WY84 was designed to obtain data necessary to assess its eligibility for nomination to the National Register of Historic Places. In order to make an assessment of the site's overall scientific value, excavations were undertaken to: 

1. Identify the vertical extent of the cultural deposit.

2. Determine the physical integrity of the deposit.

3. Identify and document the presence of any features and/or isolatable activity areas.

4. Determine site age.

It was also hoped that the data derived from the excavations would help to test and refine the preliminary interpretations of the local archeological record developed by Day et al. (1981:77-78) regarding:

1. Aboriginal social group size.

2. Seasonality.

3. Natural resource exploitation.

4. Nonlocal resource procurement/trade.

5. Hunting, gathering, tool manufacture and food preparation activities.

6. Age range of the prehistoric occupation of the area.

\section{METHODOLOGY}

Testing at 41 WY 84 involved the manual excavation of two $2 \times 2-m$ units (Test Areas $A$ and $B$ ) and three 30-cm-diameter shovel probes. In addition, fourteen $20 \times 20-m$ units were intensively searched for surface cultural materials. All of these investigations were undertaken within the limits of the proposed Main Floodway Channel right-of-way.

A permanent reference point (site datum) was established at the southwestern corner of a concrete culvert located in the existing drainage ditch immediately west of the site. This action was necessary as no known survey points are present in the vicinity of site 4lWY84. A second, temporary reference point, N1000/W1000, was located above the drainage ditch in the northwestern site area. Using N1000/W1000 as the northwestern limit, an arbitrary grid aligned $7.5^{\circ}$ east of magnetic north was established. All investigation units are referred to by their northwestern coordinate.

Project documentation included the maintenance of daily general field notes. In addition, excavation progress was noted on a daily basis on forms designed to assist in unit/level recordkeeping. Photography, both color and black-and-white, was another method used to document the testing of site 4 lWY84 (Fig. 6). 
All of the specimens recovered from site 41 WY84 were sent to the laboratory at Prewitt and Associates, Inc. for processing and analysis. Processing of specimens included washing, labeling and cataloguing. Permanent curation has been arranged with the Texas Archeological Research Laboratory (TARL), The University of Texas at Austin.

More-detailed discussion of the techniques used for each form of data recovery is given below.

$\underline{2 \times 2-m \text { Units }}$

Excavation of Test Area $A$ involved the initial excavation of one lxl-m unit in arbitrary 10-cm-thick levels for vertical control. All fill was screened through 1/4-in mesh hardware cloth. Unit N986/W986 was to be this initial $1 \times 1-m$ square and had been started as such, but rain caused this plan to be altered. A second unit within Test Area $A$, N985/W987, was selected and excavated as the initial unit in the manner described. Test Area $A$ was selected for excavation because it occurs within a part of the site where a surface concentration of bones and fired clay lumps was found during the archeological survey. The information derived from this first test provided the basis for further testing decisions.

Stratigraphic data obtained from N985/W987 established the depth of the plowzone at the site. Upon reaching a culturally sterile zone at 60-70 $\mathrm{cm}$ below the present surface, excavation of the unit was terminated and three adjacent $1 \times 1-m$ units were excavated to form the rest of the $2 \times 2-m$ test. Excavation of these units followed closely the techniques used for N985/w987 with one exception. Specifically, in these three units only matrix from certain of the levels below the identified plowzone was screened through 1/4-in hardware cloth. In this manner, access to the probable cultural zone was expedited. The coordinates bounding Text Area A are: N986/W987, N986/W985, N984/W985 and N984/W987.

The second $2 \times 2-m$ unit, Test Area B, was located south and east of Test Area A. Like Test Area A, Test Area B showed a relative concentration of cultural materials on the present surface (Fig. 7). A modified excavation strategy was followed for Test Area B. The plowzone was removed for the entire $2 \times 2-m$ area, and the cultural zone was then excavated separately for each of the four $1 \times 1-m$ units. Furthermore, the cultural zone was excavated as a stratigraphic unit using matrix color and texture to identify its vertical extent. Only the matrix excavated from the cultural zone was screened using 1/4-in hardware cloth. Upon reaching the bottom of this cultural zone, excavation of Test $B$ was terminated. The coordinates bounding Test B are: N951/W967, N951/W965, N949/W965 and N949/W967.

All excavations at Test Areas A and B were accomplished manually, using shovels, picks and trowels. The selection of the excavation tool was dependent upon the requirements imposed by matrix conditions. At each $2 \times 2-m$ test, a temporary datum was established at the highest corner. The elevation of each of these points was recorded in relation to 
Figure 6. Photographs of site 41 WY 84.

a. View of northern site area; excavator is working in Unit N985/W987 of Test Area A.

b. General view of test excavations at Test Area A, oriented eastward. 
Figure 6

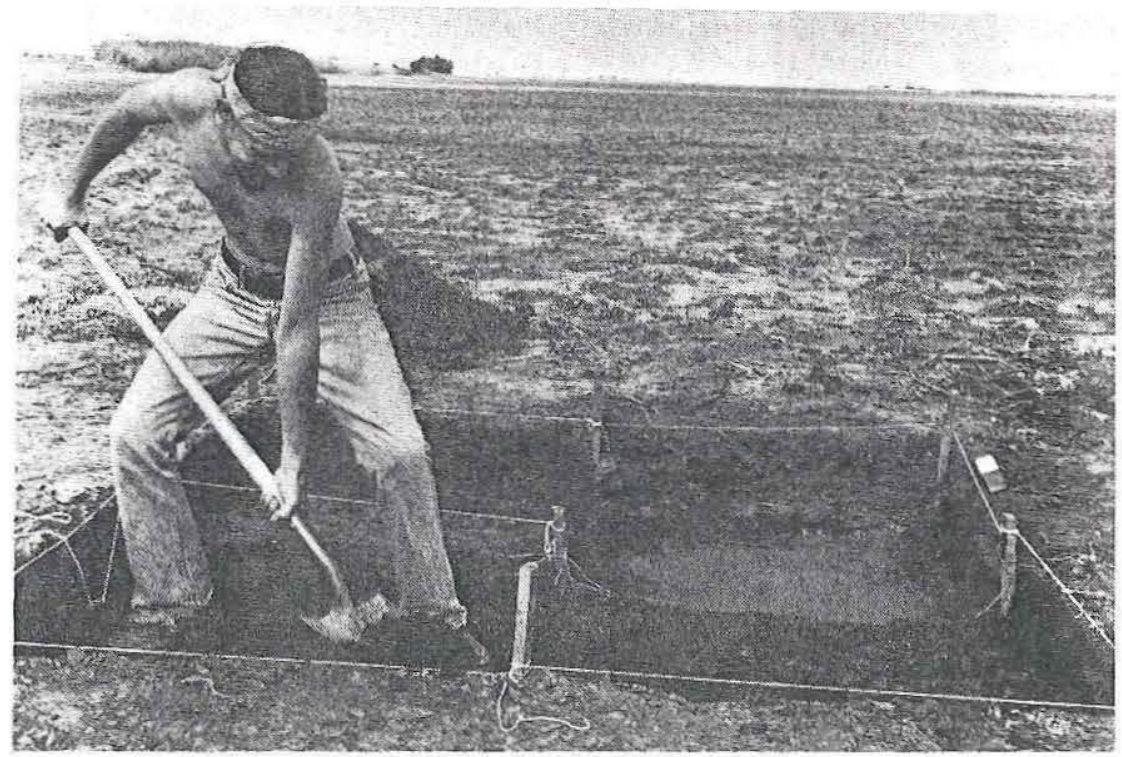

$a$

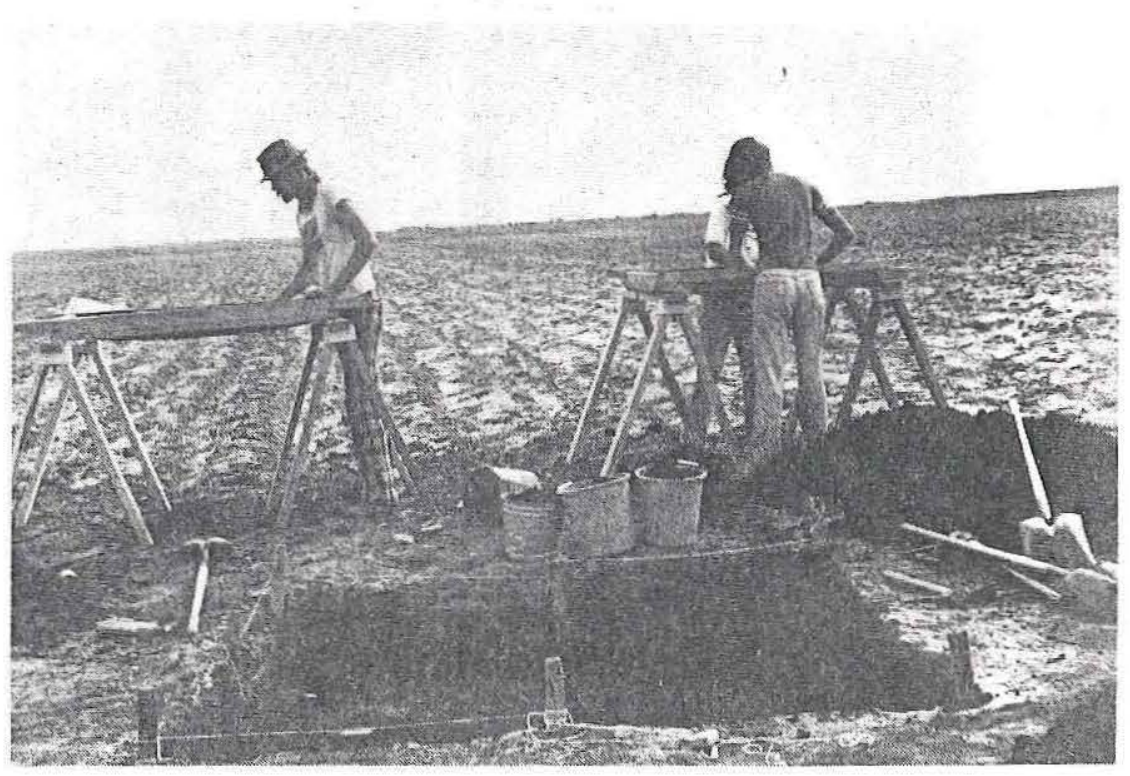


that of the permanent site datum. The temporary unit datum was then used to record relative elevations with the aid of a string line, line level and metric hand tape for all four lxl-m units of each $2 \times 2-m$ test.

All specimens recovered from Test Areas A and B were bagged according to minimum provenience unit. Bag inventory slips with provenience information and specimen data were also completed and included in each bag. Unit level forms were maintained for each level excavated and representative profiles of the completed $2 \times 2-m$ tests were drawn to scale to show site stratigraphy.

Unsieved matrix samples taken from the northeastern corner of each unit level excavated below the plowzone were collected from Test Areas A and B. Plowzone samples were taken from units N985/W987 and N986/W986 only. The amount gathered for each sample filled approximately onethird of a \#20 bag. After returning to the laboratory, about 800 cubic $\mathrm{cm}$ was selected from each sample and retained. The remainder of each sample was then discarded.

Excavation information for Test Areas $A$ and $B$ is summarized in Table 6. Schematic drawings showing the units in each Test Area is provided in Figure 8.

Shovel Probes

Three shovel probes were excavated near the following grid points: N920/W965, N900/W965 and N880/W965. The stratigraphic information obtained from the two $2 \times 2-m$ units was used to identify the plow and cultural zones. Cultural zone matrix was sieved through 1/4-in hardware cloth. Each probe was terminated at the bottom of the cultural zone, the maximum depth being about $43 \mathrm{~cm}$ below the present surface.

\section{Surface Collection Units}

Fourteen $20 \times 20-m$ units were thoroughly searched for surface cultural materials. All specimens encountered were collected and their location noted with other pertinent data on surface collection forms. The specimens recovered within each $20 \times 20-m$ area were placed in separate, appropriately labeled bags.

\section{SITE DESCRIPTION}

Site 41 WY84 is situated between two northwest-southeast trending relict interdistributary channel scars southeast of Willamar, Texas. During the initial survey and assessment, cultural materials were detected both in a plowed field and in a cutbank of an adjacent earthen drainage ditch. This drainage ditch runs generally north-south parallel to the western edge of the site for a distance of $.36 \mathrm{~km}$, and turns eastward to parallel the southern edge of the site. 


$$
\square
$$


TABLE 6

EXCAVATION INFORMATION ( $1 \times 1-m$ Units)

\begin{tabular}{|c|c|c|c|c|c|c|c|c|c|}
\hline \multirow[t]{2}{*}{. } & & \multicolumn{4}{|c|}{ Test Area A } & \multicolumn{4}{|c|}{ Test Area B } \\
\hline & & N986/W987 & N986/W986 & N985/W987 & N985/W986 & N951/W967 & N951/W966 & N950/W967 & N950/W966 \\
\hline Level 1 & & $\begin{array}{l}\text { Removed* } \\
\text { Overburden }\end{array}$ & $\begin{array}{l}0-10 \mathrm{~cm} / * * \\
1.301-1.201 \\
\text { m (I) }\end{array}$ & $\begin{array}{l}\text { Removed } \\
\text { Overburden }\end{array}$ & $\begin{array}{l}\text { Removed } \\
\text { Overburden }\end{array}$ & $\begin{array}{l}\text { Removed } \\
\text { Overburden }\end{array}$ & $\begin{array}{l}\text { Removed } \\
\text { Overburden }\end{array}$ & $\begin{array}{l}\text { Removed } \\
\text { Overburden }\end{array}$ & $\begin{array}{l}\text { Removed } \\
\text { Overburden }\end{array}$ \\
\hline Level 2 & & $\begin{array}{l}\text { Removed } \\
\text { Overburden }\end{array}$ & $\begin{array}{l}10-20 \mathrm{~cm} / \\
1.201-1.101 \\
\mathrm{~m} \text { (II) }\end{array}$ & $\begin{array}{l}\text { Removed } \\
\text { Overburden }\end{array}$ & $\begin{array}{l}\text { Removed } \\
\text { Overburden }\end{array}$ & $\begin{array}{l}\text { Removed } \\
\text { Overburden }\end{array}$ & $\begin{array}{l}\text { Removed } \\
\text { Overburden }\end{array}$ & $\begin{array}{l}\text { Removed } \\
\text { Overburden }\end{array}$ & $\begin{array}{l}\text { Removed } \\
\text { Overburden }\end{array}$ \\
\hline Level 3 & . & $\begin{array}{l}20-30 \mathrm{~cm} / \\
1.175-1.075 \\
\mathrm{~m} \text { (II) }\end{array}$ & $\begin{array}{l}20-30 \mathrm{~cm} / \\
1.101-1.001 \\
\mathrm{~m} \text { (II) }\end{array}$ & $\begin{array}{l}20-30 \mathrm{~cm} / \\
1.185-1.085 \\
\mathrm{~m} \text { (II) }\end{array}$ & $\begin{array}{l}\text { Removed } \\
\text { Overburden }\end{array}$ & $\begin{array}{l}22-39 \mathrm{~cm} / \\
1.04-.87 \mathrm{~m} \\
\text { (II, III) }\end{array}$ & $\begin{array}{l}20-33 \mathrm{~cm} / \\
1.06-.93 \mathrm{~m} \\
\text { (III) }\end{array}$ & $\begin{array}{l}27-38 \mathrm{~cm} / \\
.99-.88 \mathrm{~m} \\
\text { (III) }\end{array}$ & $\begin{array}{l}23-34 \mathrm{~cm} / \\
1.03-.92 \mathrm{~m} \\
\text { (III) }\end{array}$ \\
\hline Level 4 & & $\begin{array}{l}30-40 \mathrm{~cm} / \\
1.075-.975 \mathrm{~m} \\
\text { (II, III) }\end{array}$ & $\begin{array}{l}30-40 \mathrm{~cm} / \\
1.001-.901 \mathrm{~m} \\
\text { (III) }\end{array}$ & $\begin{array}{l}30-40 \mathrm{~cm} / \\
1.985-.985 \mathrm{~m} \\
\text { (II, III) }\end{array}$ & $\begin{array}{l}\text { Removed } \\
\text { Overburden }\end{array}$ & --- & --- & -- & -- \\
\hline Level 5 & & $\begin{array}{l}40-50 \mathrm{~cm} / \\
.975-.875 \mathrm{~m} \\
\text { (III) }\end{array}$ & $\begin{array}{l}40-50 \mathrm{~cm} / \\
.901-801 \mathrm{~m} \\
(I I I, I V))\end{array}$ & 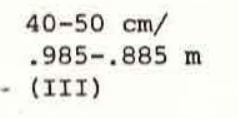 & $\begin{array}{l}40-50 \mathrm{~cm} / \\
.975-.875 \mathrm{~m} \\
\text { (III, IV) }\end{array}$ & -- & --- & -- & --- \\
\hline Level 6 & & --- & -- & $\begin{array}{l}50-60 \mathrm{~cm} / \\
.885-.785 \mathrm{~m} \\
(\mathrm{IV}, \mathrm{V})\end{array}$ & --- & --- & -- & -- & -- \\
\hline Level 7 & & -- & --- & $\begin{array}{l}60-70 \mathrm{~cm} / \\
.785-.685 \mathrm{~m} \\
\text { (V) }\end{array}$ & -- & --- & --- & -- & -- \\
\hline
\end{tabular}

*Removed Overburden $=$ plowzone discarded.

**Depth below surface/elevation above datum: numbers in parentheses indicate strata identified in each level. 


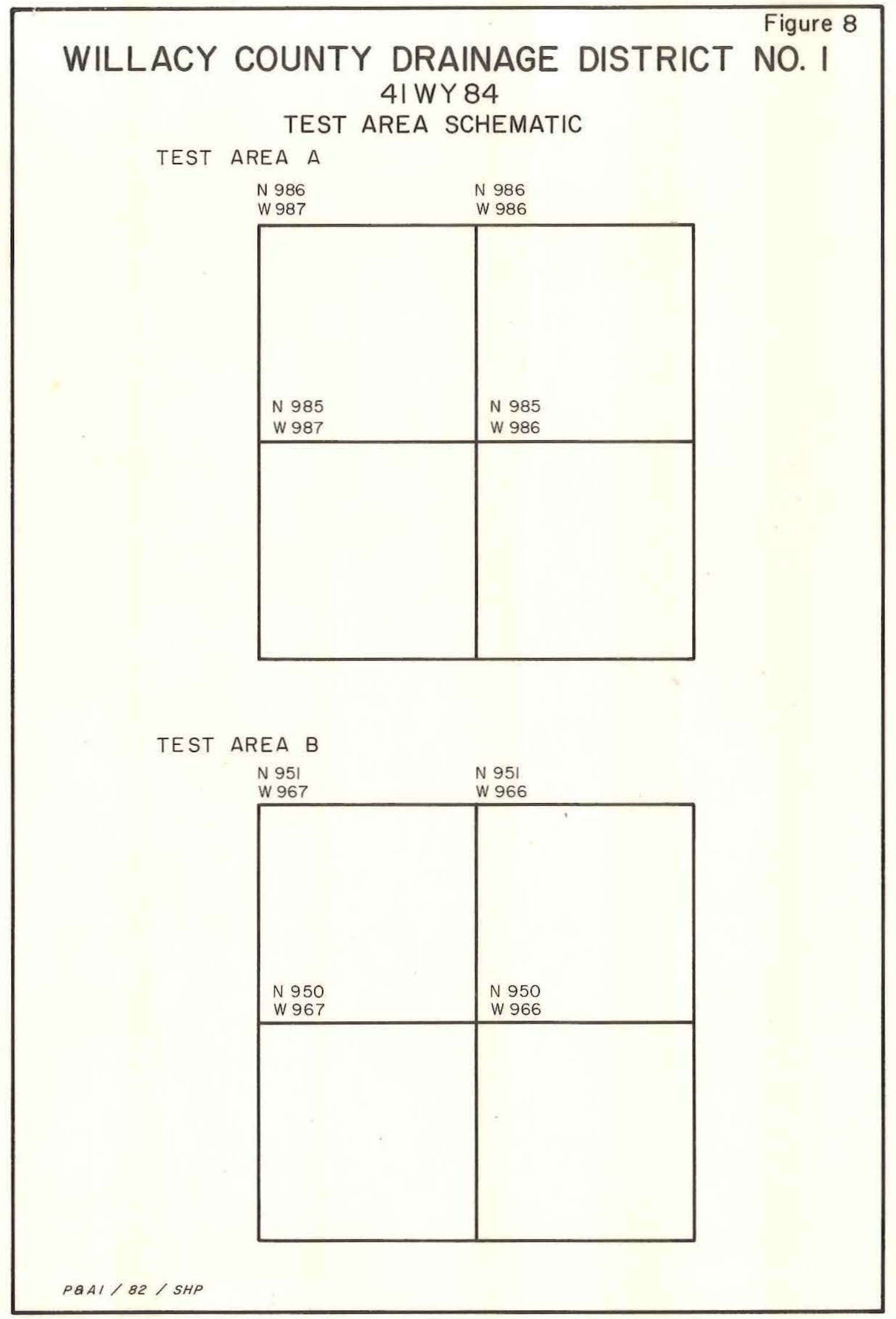


During the testing, the drainage ditch was holding a small amount of water. Vegetation was limited to the ditch cutbanks and consisted of bermudagrass, johnsongrass, sunflowers and a few isolated mesquites. Cotton is the usual crop planted in the field but had been harvested prior to testing. Surface visibility therefore varied from 30 to 100 percent along the ditch and was 100 percent in the field.

Elevations recorded during the testing are approximate due to the lack of known survey points in the area. Mapping efforts were able to establish, however, that the elevations of the site vary within a 20-cm range at approximately 6.0-6.2 m (20.0-20.6 ft) above $\mathrm{msl}$. The drainage ditch elevations range over $2.4 \mathrm{~m}$, from approximately $6.7 \mathrm{~m}(22.3 \mathrm{ft})$ above msl at its highest point to approximately $4.3 \mathrm{~m}(14.3 \mathrm{ft})$ above msl at the bottom of the ditch (see Fig. 8).

\section{STRATIGRAPHIC INFORMATION}

Test excavations revealed five discernible strata at 41 WY 84 . The description of each is presented below from top to bottom, based on field identifications made by Archeological Assistant Ron Holan and the Project Archeologist.

References to matrix color are standardized Munsell soil color designations (Munsell Color Co. 1975). It should also be noted that determinations of moisture levels are somewhat biased as a locally intense rainfall occurred during the project.

Figure 9 presents a compilation of stratigraphic information in the form of generalized cross sections and selected profiles from the site. Table 6 also contains stratigraphic information.

\section{Stratum I}

Stratum I is a fairly unconsolidated surface plowzone. It is made up of hard and blocky clods of dry, very dark grayish brown sjlty loam (IOYR 3/2) within a loose matrix of gray sand (IOYR 5/2). Crop trash such as roots and woody material was found mixed throughout the stratum. No established root system was present, nor were any inclusions observed. Only one burrowing disturbance was encountered, at the base of Stratum I in Test Area A.

The thickness of Stratum I varies from 2.5 to $13.5 \mathrm{~cm}$. This variation is probably a result of continuous cultivation. In viewing this uppermost layer in cross section, it is apparent that the maximum depth occurs between 1.2 and $1.1 \mathrm{~m}$ above site datum.

\section{Stratum II}

Stratum II is a more compacted zone. The matrix is slightly moist, very dark grayish brown (lOYR 3/2) silty loam. Its texture is slightly gritty, indicating the presence of sand. A small number of sand inclusions and burrowing disturbances were encountered in this stratum. The 


\section{WILLACY COUNTY DRAINAGE DISTRICT NO.I 41 WY 84}

GENERALIZED CROSS SECTIONS

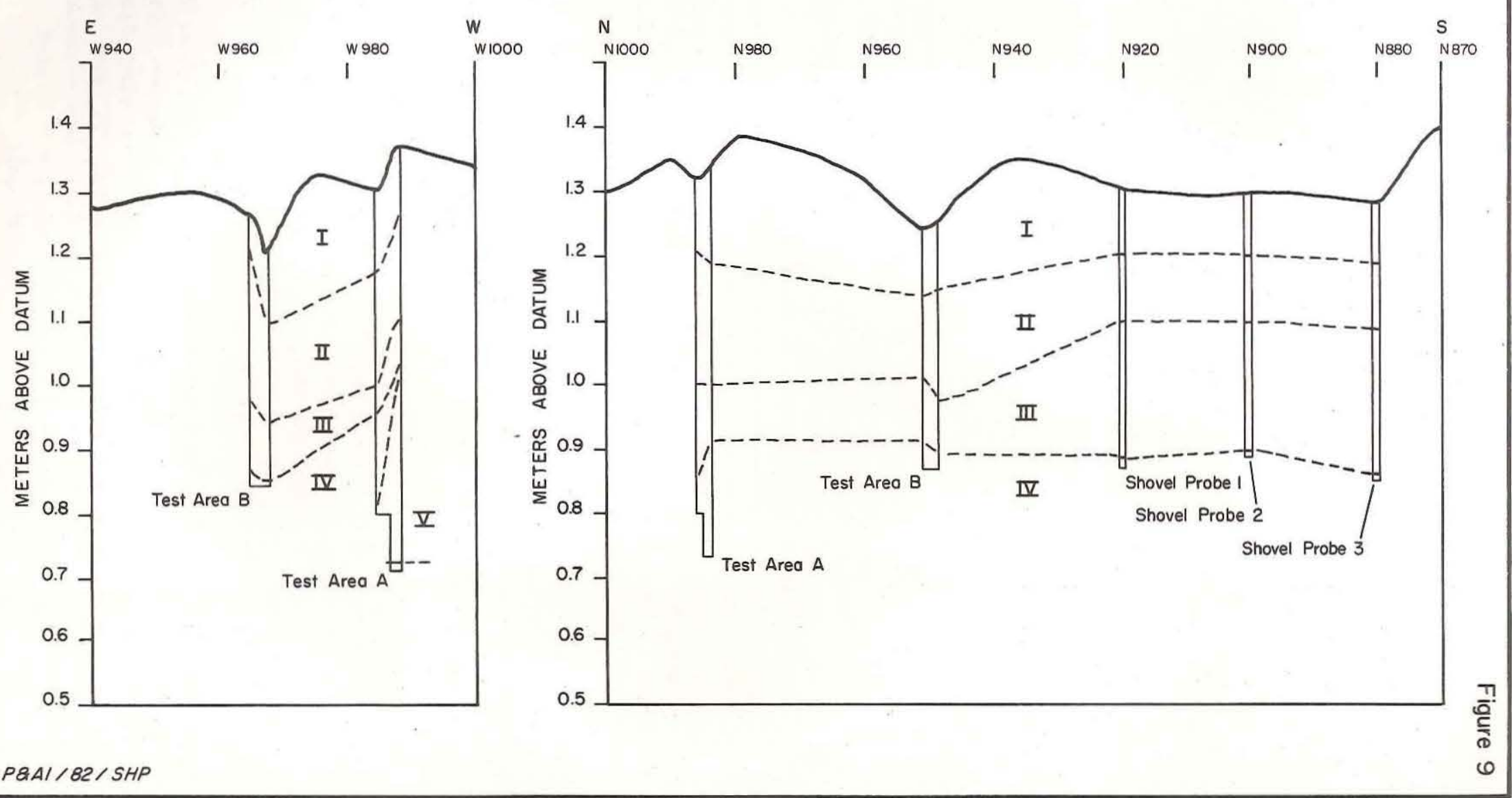




\section{Stratum V}

In unit N985/W987 of Test Area A, a stratum of extremely compact brown (IOYR 4/3) clay was encountered. The moisture level of this clay is slightly less than that observed in Strata III and IV. Absent from this layer are disturbances and inclusions.

The vertical extent and thickness of this stratum were not determined due to the termination of excavations at $0.685 \mathrm{~m}$ above datum. Nonetheless, observations made in the adjacent drainage ditch indicate that this stratum continues below this depth.

TEST RESULTS

Ninety-two specimens were recovered from testing at site 4lWY84. With the material collected during the earlier survey, this brings the total site assemblage to 103 specimens. These items are classified according to basic physical characteristics, thus producing five analytical categories: knapped stone, faunal remains, fired clay lumps/ balls, charcoal flecks and metal. A graph summarizing the assemblage is provided in Figure 10.

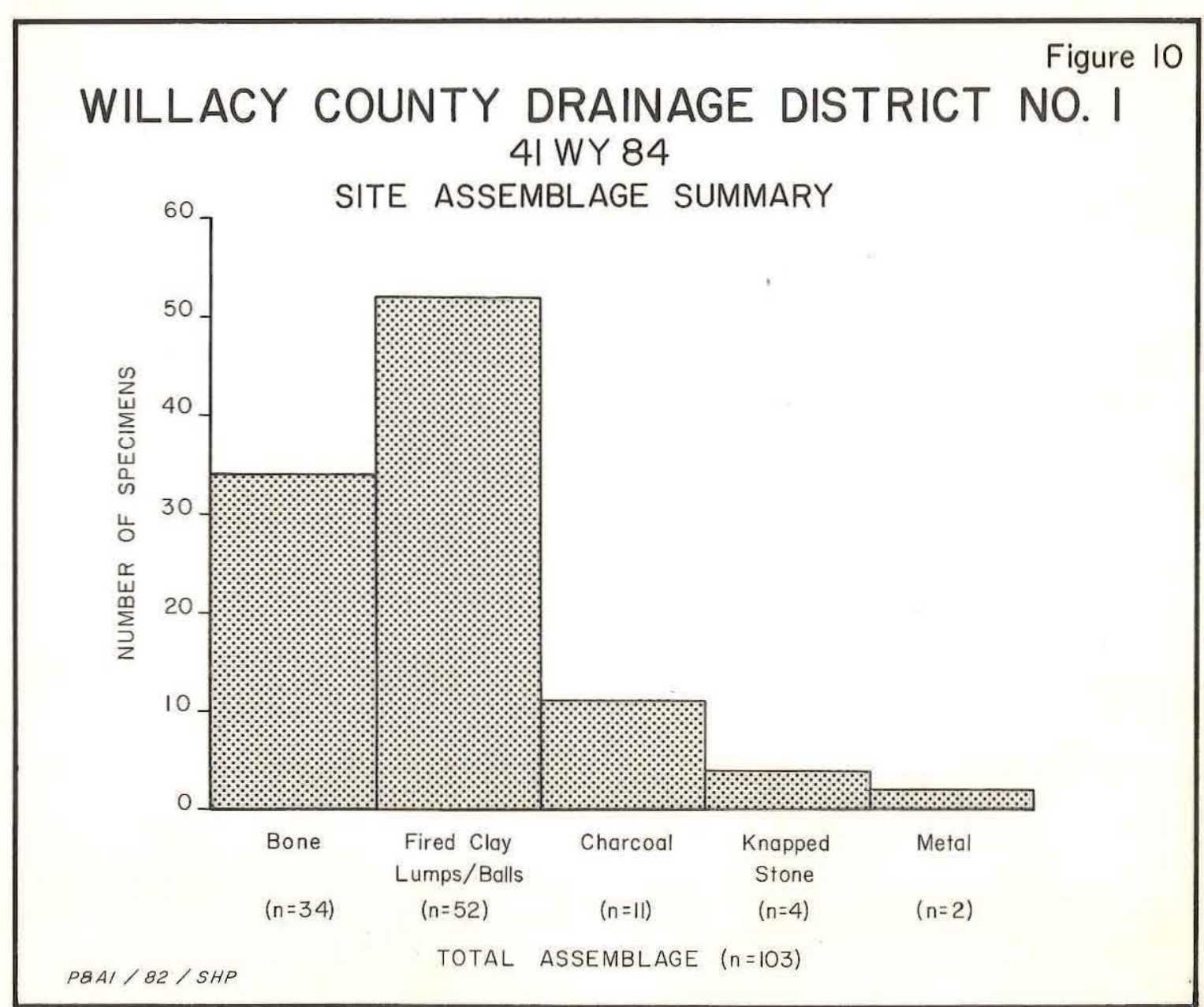


The site assemblage is described in detail below and is arranged by analytical category. The presentation and terminology used is compatible with Day (1981), Day et al. (1981) and the earlier work of Mallouf et al. (1977). Tables 7 through 9 present provenience data for the materials recovered during both phases of investigation.

TABLE 7

41WY84: SURVEY ASSEMBLAGE

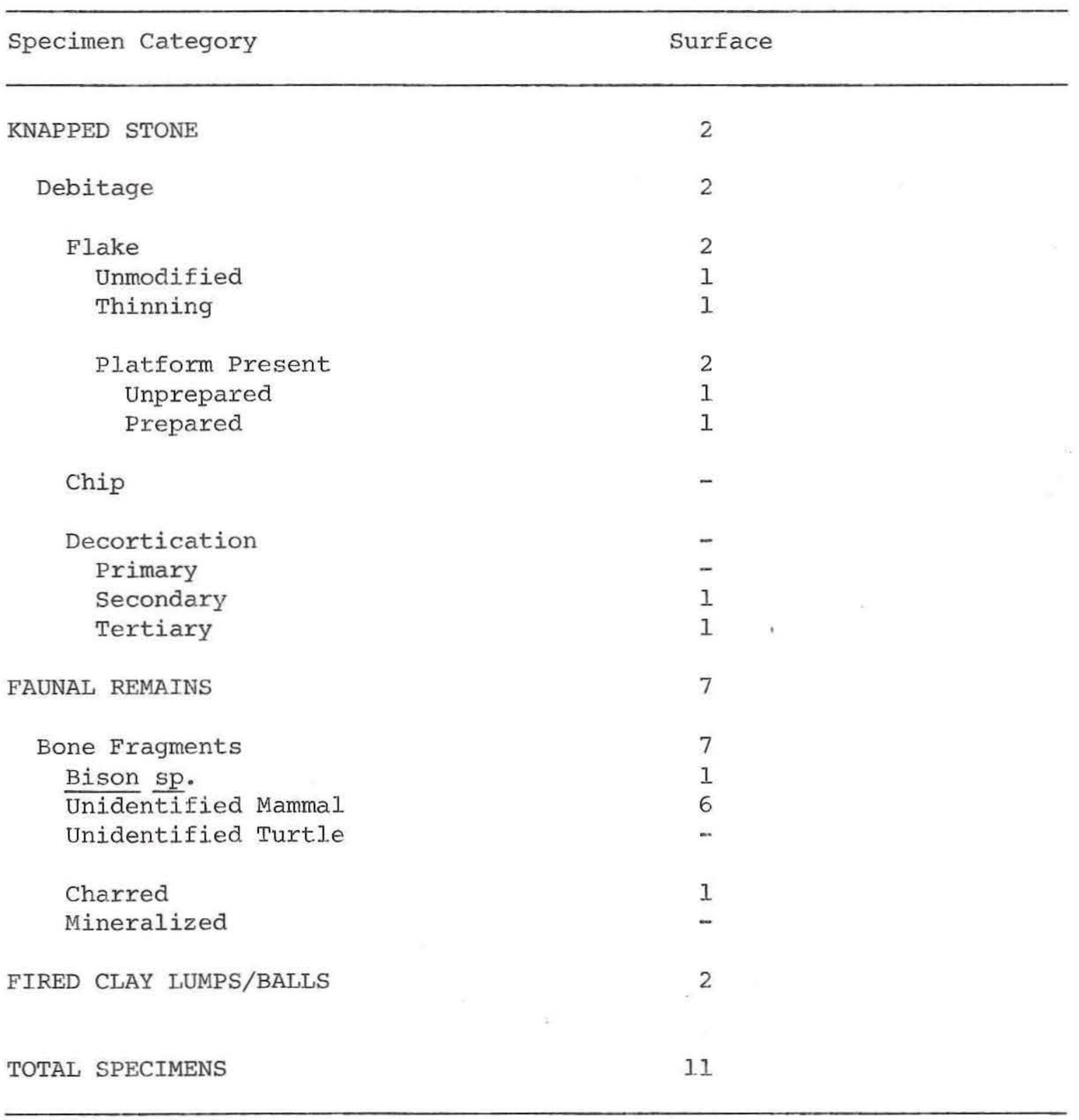


TABLE 8

4.1WY84: 20x20-m SURFACE COLLECTION UNITS, PROVENIENCE DATA

\begin{tabular}{|c|c|c|c|c|c|c|c|c|c|}
\hline Specimen Category & $\begin{array}{l}\text { N980/ } \\
\text { W985 }\end{array}$ & $\begin{array}{l}\text { N960/ } \\
\text { W985 }\end{array}$ & $\begin{array}{l}\text { N940/ } \\
\text { W985 }\end{array}$ & $\begin{array}{l}\text { N920/ } \\
\text { W985 }\end{array}$ & $\begin{array}{l}\text { N900/ } \\
\text { W985 }\end{array}$ & $\begin{array}{l}\text { N1000/ } \\
\text { W965 }\end{array}$ & $\begin{array}{l}\text { N980/ } \\
\text { W965 }\end{array}$ & $\begin{array}{l}\text { N960/ } \\
\text { W965 }\end{array}$ & $\begin{array}{l}\text { N920/ } \\
\text { W965 }\end{array}$ \\
\hline FAUNAI REMAINS & - & 1 & 1 & 2 & 1 & - & - & 1 & 2 \\
\hline Bone Fragments & - & 1 & 1 & 2 & 1 & - & - & 1 & 2 \\
\hline Bison sp. & - & - & - & - & - & - & - & - & - \\
\hline Unidentified Mammal & - & 1 & 1 & 2 & 1 & - & - & 1 & - \\
\hline Unidentified Turtle & - & - & - & - & - & - & - & - & 2 \\
\hline Element Identified & - & - & - & - & 1 & - & - & - & - \\
\hline Epiphysis & - & - & - & - & 1 & - & - & - & - \\
\hline FIRED CLAY LUMPS/BALLS & 4 & 2 & 2 & 2 & - & 1 & 2 & 1 & - \\
\hline CHARCOAL FLECKS & - & 1 & - & - & - & - & - & - & - \\
\hline METAL & - & 1 & - & - & - & - & - & - & - \\
\hline Sheet Fragment & - & 1 & - & - & - & - & - & - & - \\
\hline Shotgun Shell & - & - & - & - & - & - & - & - & - \\
\hline TOTAL SPECIMENS & 4 & 5 & 3 & 4 & 1 & 1 & 2 & 2 & 2 \\
\hline
\end{tabular}


TABLE 9

4IWY84: 1 1 1-m EXCAVATION UNITS PROVENIENCE DATA

\begin{tabular}{|c|c|c|c|c|c|c|c|c|c|c|c|c|c|c|}
\hline \multirow[b]{3}{*}{ Specimen Category } & \multicolumn{14}{|c|}{ Test Area A } \\
\hline & \multicolumn{3}{|c|}{ N986/W987 } & \multicolumn{5}{|c|}{ N986/W986 } & \multicolumn{5}{|c|}{ N985/W987 } & \multirow{2}{*}{$\frac{N 985 / W 986}{L-5}$} \\
\hline & $L-3$ & $I-4$ & $\mathrm{~L}-5$ & $L-1$ & $\mathrm{~L}-2$ & $L-3$ & $\mathrm{~L}-4$ & $I-5$ & $L-3$ & $\mathrm{~L}-4$ & $L-5$ & $L-6$ & $\mathrm{~L}-7$ & \\
\hline KNAPPED STONE & - & - & - & I & 1 & - & - & - & - & - & - & - & - & - \\
\hline Debitage & - & - & - & 1 & 1 & - & - & - & - & - & - & - & - & - \\
\hline Flake & - & - & - & - & - & - & - & - & - & - & - & - & - & - \\
\hline Unmodified & - & - & - & - & - & - & - & - & - & - & - & - & - & - \\
\hline Modified. & - & - & - & - & - & - & - & - & - & - & - & - & - & - \\
\hline Platform Present & - & - & - & - & - & - & - & - & - & - & - & - & - & - \\
\hline Unprepared & - & - & - & - & - & - & - & - & - & - & - & - & - & - \\
\hline Prepared & - & - & - & - & - & - & - & - & - & - & - & - & - & - \\
\hline Chip & - & - & - & 1 & 1 & - & - & - & - & - & - & - & - & - \\
\hline Decortication & - & - & - & - & - & - & - & - & - & - & - & - & - & - \\
\hline Primary & - & - & - & - & - & - & - & - & - & - & - & - & - & - \\
\hline Secondary & - & - & - & 1 & - & - & - & - & - & - & - & - & - & - \\
\hline Tertiary & - & - & - & - & 1 & - & - & - & - & - & - & - & - & - \\
\hline FAUNAL REMAINS & 1 & 1 & - & - & 1 & - & 1 & - & 2 & - & - & 1 & - & - \\
\hline Bone Fragments & 1 & 1 & - & - & 1 & - & 1 & - & 2 & - & - & 1 & - & - \\
\hline$\frac{\text { Bison sp. }}{\text { Unidentified }}$ & - & 1 & - & - & - & - & - & - & - & - & - & - & - & - \\
\hline Mammal & 1 & - & - & - & 1 & - & 1 & - & 2 & - & - & 1 & - & - \\
\hline Turtle & - & - & - & - & - & - & - & - & - & - & - & - & - & - \\
\hline
\end{tabular}


Table 9, continued

\begin{tabular}{|c|c|c|c|c|c|c|c|c|c|c|c|c|c|c|}
\hline \multirow[b]{3}{*}{ Specimen Category } & \multicolumn{14}{|c|}{ Test Area A } \\
\hline & \multicolumn{3}{|c|}{ N986/W987 } & \multicolumn{5}{|c|}{ N986/W986 } & \multicolumn{5}{|c|}{ N985/W987 } & \multirow{2}{*}{$\frac{\text { N985/W986 }}{\text { L-5 }}$} \\
\hline & $I-3$ & $L-4$ & $L-5$ & L-1 & $L-2$ & $L-3$ & $L-4$ & $L-5$ & $I-3$ & $L-4$ & $L-5$ & $I-6$ & $L-7$ & \\
\hline Element & & & & & & & & & & & & & & \\
\hline Identified & - & 1 & - & - & - & - & - & - & - & - & - & - & - & - \\
\hline Femur & - & - & - & - & - & - & - & - & - & - & - & - & - & - \\
\hline Humerus & - & - & - & - & - & - & - & - & - & - & - & - & - & - \\
\hline Phalange (3rd) & - & 1 & - & - & - & - & - & - & - & - & - & - & - & - \\
\hline Vertebra & - & - & - & - & - & - & - & - & - & - & - & - & - & - \\
\hline Charred & - & - & - & - & - & - & - & - & - & - & - & - & - & - \\
\hline Mineralized & - & 1 & - & - & - & - & - & - & - & - & - & - & - & - \\
\hline $\begin{array}{l}\text { Terrestrial Snail } \\
\text { Shell }\end{array}$ & * & * & * & * & * & * & * & * & * & * & * & $*$ & * & * \\
\hline $\begin{array}{l}\text { FIRED CLAY LUMPS/ } \\
\text { BALLS }\end{array}$ & - & 3 & - & - & - & - & 11 & 2 & 7 & 1 & - & - & - & - \\
\hline CHARCOAL FLECKS & 2 & 1 & - & - & 1 & 1 & 1 & - & 3 & - & - & - & - & - \\
\hline METAL & - & - & - & - & - & - & - & - & - & - & - & - & - & - \\
\hline Sheet Fragment & - & - & - & - & - & - & - & - & - & - & - & - & - & - \\
\hline Shotgun Shell & - & - & - & - & - & - & - & - & - & - & - & - & - & - \\
\hline TOTAL SPECIMENS & 3 & 5 & - & 1 & 3 & 1 & 13 & 2 & 12 & 1 & - & 1 & - & - \\
\hline
\end{tabular}

* Indicates specimen category present. 
Table 9, continued

Test Area B

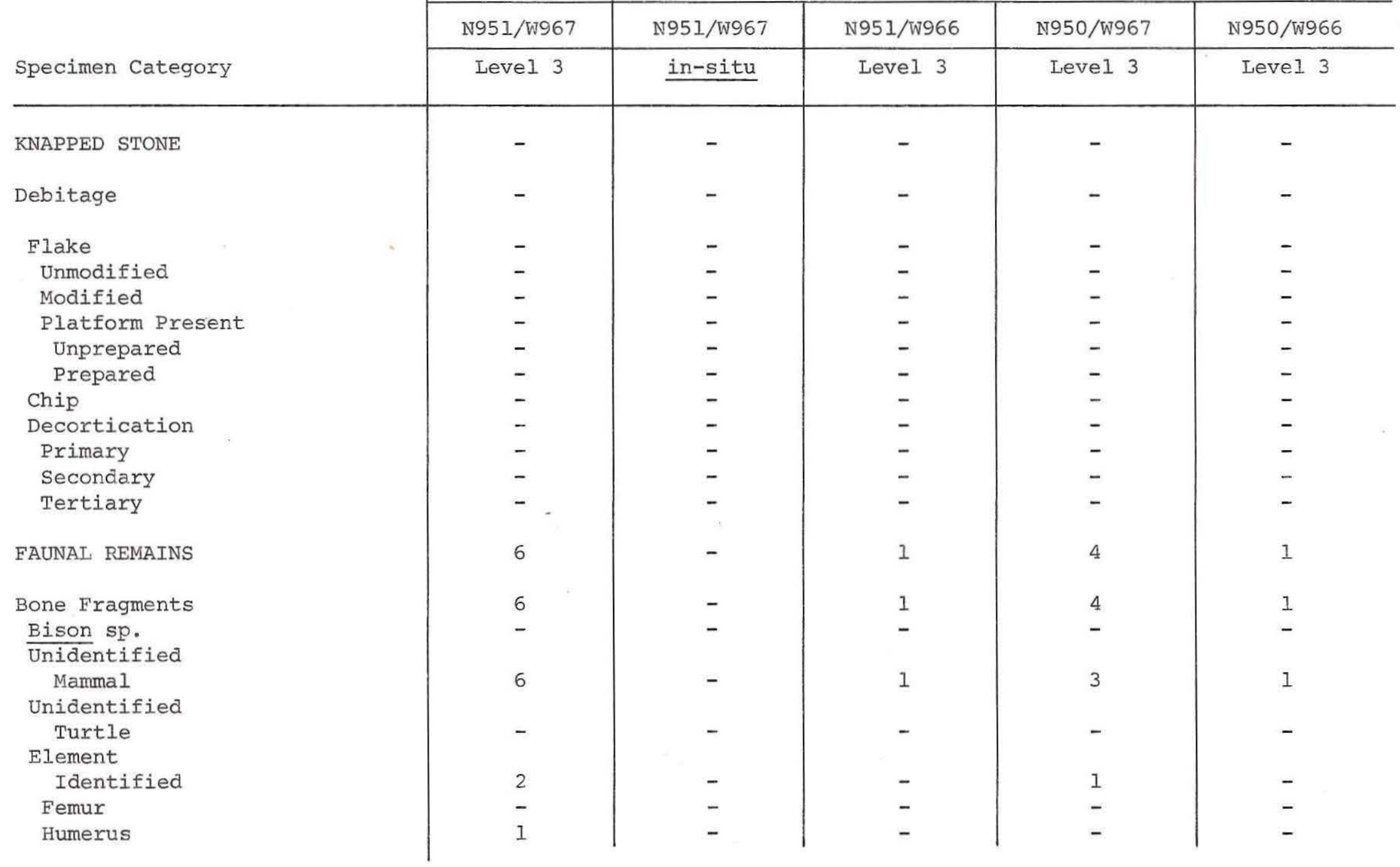


Table 9, continued

Test Area B

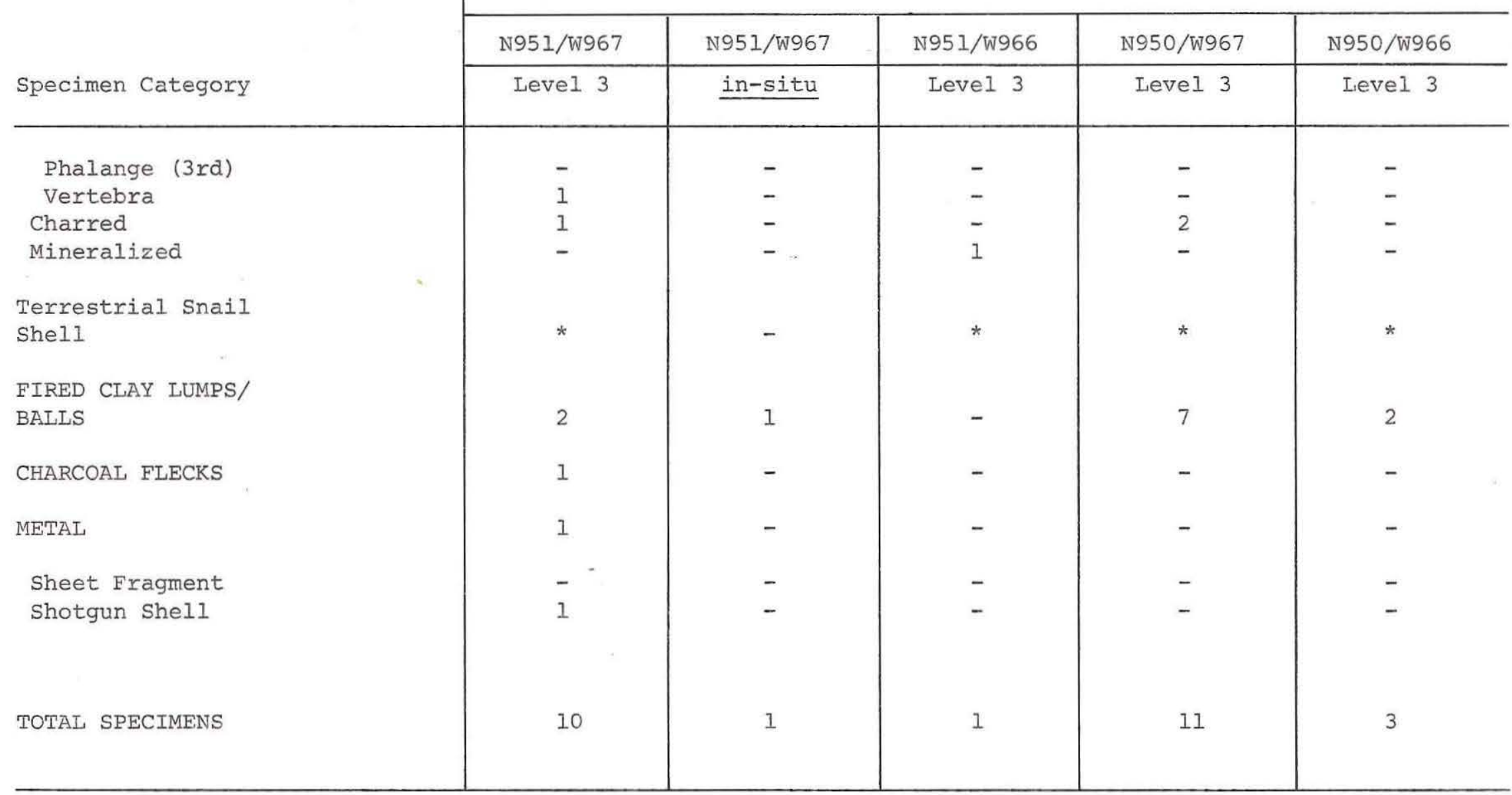




\section{SPECIMEN DESCRIPTIONS}

Identifications are made using general descriptive divisions and progress to more precise subcategories when possible. The materials recovered from the earlier survey project are described in Part I of this report.

\section{Knapped Stone}

The intentional removal of flakes from stone in the process of tool manufacture and use is reflected in the archeological record as finished tools and chipping debris (debitage). At site 4lWY84, debitage is the only recovered evidence of these activities. The survey assemblage includes two pieces of debitage. Testing yielded two additional specimens:

\section{(1) Specimen 1}

Description: Secondary chip with no platform discernible. The outline is generally rectangular with fairly straight edges. No other modification could be detected.

Cross Section: Planoconvex.

Material: Light gray fine-grained quartzite.

Dimensions: Length, $14.34 \mathrm{~mm}$; Width, $7.26 \mathrm{~mm}$; Thickness, 3.22

$\mathrm{mm}$.

Provenience: N986/W986, Level 1 (1.301-1.201 m above datum).

(2) Specimen 2

Description: Rectangular chip with straight and broken edges. A small portion of the platform is present and exhibits cortex. No other modification was noted on the specimen.

Cross Section: Tabular.

Material: orange coarse-grained quartzite.

Dimensions: Length, $8.27 \mathrm{~mm}$; Width, $6.25 \mathrm{~mm}$; Thickness, 2.20

$\mathrm{mm}$.

\section{Faunal Remains}

Thirty-four bone fragments were recovered from 41WY84. As indicated in Part I, seven fragments were collected during the initial recording of the site. The survey collection included one Bison sp. fragment with a cut edge as well as six mammalian fragments, one of which is charred. 
Most of the faunal remains recovered during the testing project are unidentifiable fragments. Only three specimens exhibit charring, and one is mineralized. All were recovered from Test Area B. A small number of fragments can be identified further:

N900/W985 (Surface): Unidentified mammal, possible epiphysis fragment.

N986/W987 (Level 4): Probably Bison sp.; third phalanx fragment, articular surface mineralized (Olsen 1969).

N951/W967 (Level 3): One vertebra and one distal humerus, both rodent-sized mammal.

N950/W967 (Level 3): One rodent-sized mammalian distal femur.

Terrestrial snail shell was also recovered during test excavations for general density comparisons. Table 10 indicates that terrestrial snail shells were present in each of the screened levels at Test Areas A and $B$. The three shovel probes also produced snail material. The shell recovered from screening is in such fragmentary condition that it cannot be accurately speciated. Some of the more complete shells appear to belong to the genus of Rabdotus. Table 10 presents the occurrence of terrestrial snails in weight measurements.

Fired Clay Lumps/Balls

Clay lumps or balls with varying degress of thermal alteration are commonly encountered in the project area. It has been documented that these items were used prehistorically in hearth features due to the lack of stone resources (Mallouf et al. 1977:189). However, this is not the only process which produces clay lumps. Land clearing for agricultural. purposes includes the burning of vegetation which also produces fired clay specimens. Thus, the fired clay lumps recovered from the disturbed strata at 41 WY84 have dubious cultural associations. Nonetheless, all specimens encountered at the site were collected.

Two clay lumps were collected during survey investigations -- one subcircular and one amorphous in shape. The coloration of the subcircular specimen grades from reddish yellow $(7.5 \mathrm{YR} 7 / 6)$ to yellowish red $(5$ YR 5/6). The amorphous shaped lump is yellow $(10 Y R$ 7/6) in color.

Fifty additional clay lumps were recovered during the testing project. Sixteen of these were collected from the surface. The remainder were retrieved from the screening of excavated matrix with one exception. One large fired clay lump was encountered in Level 3 of Unit N951/W967 and recorded in situ. This specimen grades in color from brownish yellow (10YR $6 / 6$ ) to reddish yellow $(7.5 \mathrm{YR} 6 / 6)$. The maximum dimension of this large lump is $51 \mathrm{~mm}$ and its shape is amorphous.

A summary of the physical characteristics of the fired clay lump/ ball specimens recovered from site 41 WY 84 is presented in Table 11 . The 


\begin{tabular}{|c|c|c|c|c|c|c|c|c|}
\hline \multirow[b]{3}{*}{ Excavation Levels: } & \multicolumn{2}{|c|}{ OCCURRENCE OF } & \multicolumn{2}{|c|}{$\begin{array}{l}\text { TERRESTRIAL SNAILS } \\
\text { SITE } 4 \text { IWY } 84\end{array}$} & \multicolumn{2}{|l|}{ (IN GRAMS) } & & \\
\hline & & Test & rea $\mathrm{A}$ & & & Test & rea $B$ & \\
\hline & $\begin{array}{l}\text { N986/ } \\
\text { W987 }\end{array}$ & $\begin{array}{l}\text { N986/ } \\
\text { W986 }\end{array}$ & $\begin{array}{l}\text { N985/ } \\
\text { W987 }\end{array}$ & $\begin{array}{l}\text { N985/ } \\
\text { W986 }\end{array}$ & $\begin{array}{l}\text { N951/ } \\
\text { W967 }\end{array}$ & $\begin{array}{l}\text { N951/ } \\
\text { W966 }\end{array}$ & $\begin{array}{l}\text { N950/ } \\
\text { W967 }\end{array}$ & $\begin{array}{l}\text { N950/ } \\
\text { W966 }\end{array}$ \\
\hline Level 1 & - & 3.6 & - & - & - & - & - & - \\
\hline Level 2 & - & 4.4 & - & - & - & - & - & - \\
\hline Level 3 & 14.5 & 6.6 & 19.0 & - & 0.8 & 1.1 & 0.8 & 1.3 \\
\hline Level 4 & 7.5 & 9.1 & 4.4 & - & $\mathrm{N} / \mathrm{E}$ & $\mathrm{N} / \mathrm{E}$ & $N / E$ & $\mathrm{~N} / \mathrm{E}$ \\
\hline Level 5 & 3.3 & 4.2 & 20.6 & 26.9 & $\mathrm{~N} / \mathrm{E}$ & $\mathrm{N} / \mathrm{E}$ & $\mathrm{N} / \mathrm{E}$ & $\mathrm{N} / \mathrm{E}$ \\
\hline Level 6 & $\mathrm{~N} / \mathrm{E}$ & $-\mathrm{N} / \mathrm{E}$ & 40.4 & $N / E$ & $\mathrm{~N} / \mathrm{E}$ & $\mathrm{N} / \mathrm{E}$ & $\mathrm{N} / \mathrm{E}$ & $\mathrm{N} / \mathrm{E}$ \\
\hline Level 7 & $\mathrm{~N} / \mathrm{E}$ & $\mathrm{N} / \mathrm{E}$ & 19.5 & $N / E$ & $\mathrm{~N} / \mathrm{E}$ & $\mathrm{N} / \mathrm{E}$ & $\mathrm{N} / \mathrm{E}$ & $\mathrm{N} / \mathrm{E}$ \\
\hline $\begin{array}{lll}* & \text { not screened } \\
\text { N/E: } & \text { not excavated }\end{array}$ & & & & & & & & \\
\hline
\end{tabular}


characteristics considered include shape, color (based on the Munsell categories) and maximum dimension. Color determinations represent the primary coloration for each specimen and do not consider gradations.

TABLE 11

41WY84: CLAY LUMP/BALL

PHYSICAL CHARACTERISTICS

\section{Total Surface \\ Specimens}

Total Subsurface

Specimens

I. Shape

Amorphous

Circular

Subcircular

$\begin{array}{lr}8 & 14 \\ - & 2 \\ 8 & 20\end{array}$

II. Color

Yellow (7.5 YR 7/6)

38

Reddish Yellow (7.5YR 6/6)

Yellowish Red (5YR 5/6)

98

Yellowish Brown (10YR 5/4)

48

Brownish Yellow (10YR 6/6)

$\begin{array}{ll}- & 10\end{array}$

$-$

III. Size (Maximum Dimension)

$\begin{array}{llr}0-10 \mathrm{~mm} & 1 & 20 \\ 11-20 \mathrm{~mm} & 5 & 14 \\ 21-30 \mathrm{~mm} & 9 & 1 \\ 31-40 \mathrm{~mm} & - & - \\ 41-50 \mathrm{~mm} & 1 & - \\ 51-60 \mathrm{~mm} & - & 1\end{array}$

Charcoal

Eleven small flecks of charcoal were encountered at site 4 IWY84. The charcoal was of insufficient quantity and concentration for radiocarbon assay. Because of the paucity of this material, no distinction between hearth activities or recent brush burning could be made.

Metal

Two metal specimens were collected from site 4lWY84:

(1) Specimen 1

Description: Highly oxidized sheet fragment lacking surface features. 
Material: Iron

Provenience: Surface

(2) Specimen 2

Description: 12 gauge shotgun shell, too weathered to decipher brand name.

Material: Lead with iron solder.

Provenience: N951/W967, Level 3 (1.04-0.87 m above datum).

\section{SPECIMEN DISTRIBUTIONS}

Specimens from each of the analytical categories were found on the surface of site 4lWY84. The occurrence of these materials within the $20 \times 20-m$ collection units is plotted on the site map (see Fig. 7). The survey collection includes knapped stone, faunal remains and fired clay lumps. The 20×20-m collection units yielded no additional knapped stone but do contain specimens from each of the other categories.

It is important to emphasize that this site is in a field which has undergone continuous cultivation for several decades. Test excavations revealed two plowzones -- one shallow zone (Stratum I) which is believed to reflect ongoing cultivation, and one deeper zone (Stratum II) which appears to indicate deep rootplowing undertaken to clear the land of vegetation. The materials recovered from the surface and strata I and II should therefore be considered displaced. The matrix characteristics and amount of specimens recovered from Stratum III support its identification as the remnant of the original cultural deposit. Stratum IV was not thoroughly investigated but does seem to indicate a relative paucity of cultural materials.

Vertical specimen distributions are presented in Table 12. The results are given in terms of actual totals for each analytical category as well as in percentages relating to the overall site assemblage and each individual category. When the data are analyzed in this manner, the amount of disturbance at 41 WY84 is readily apparent. Over 50 percent of the assemblage was retrieved from disturbed contexts, accounting for all of the knapped stone and most of the charcoal and faunal material. Although the lower reaches of Stratum III seem fairly intact, no features or activity areas could be discerned. Cultivation and deep rootplowing have undoubtedly displaced a fair amount of what was probably a sparse cultural deposit, possibly reflecting a basic adaptation to a low resource density area (Hester 1981).

On the basis of the limited investigations undertaken, it seems that Stratum III, the cultural zone, dips slightly to the south. The only distinction detected in this stratum is in the differing densities of faunal remains in Test Areas A and B. A significantly larger amount was recovered from Test Area B. 
TABLE 12

SITE 41WY84: SPECIMEN DISTRIBUTIONS*

\begin{tabular}{|c|c|c|c|c|c|}
\hline & Surface & $\begin{array}{c}\text { Plowzone } \\
\text { (Strata I \& I }\end{array}$ & II) & $\begin{array}{l}\text { Stratum } \\
\text { III }\end{array}$ & $\begin{array}{c}\text { Stratum } \\
\text { IV }\end{array}$ \\
\hline \multicolumn{6}{|l|}{ BONE } \\
\hline Total & 15 & 4 & & 14 & 1 \\
\hline$\%$ of Assemblage & $14.5 \%$ & $4.0 \%$ & & $13.5 \%$ & $1.0 \%$ \\
\hline$\%$ of Category & $(44.0 \%)$ & $(12.0 \%)$ & & $(41.0 \%)$ & $(3.0 \%)$ \\
\hline \multicolumn{6}{|l|}{ FIRE CLAY LUMPS/BALLS } \\
\hline Total & 16 & 8 & & 26 & 2 \\
\hline$\%$ of Assemblage & $15.5 \%$ & $7.5 \%$ & & $25.0 \%$ & $2.0 \%$ \\
\hline$\%$ of Category & $(31.0 \%)$ & $(15.0 \%)$ & & $(50.0 \%)$ & $(4.0 \%)$ \\
\hline \multicolumn{6}{|l|}{ CHARCOAL } \\
\hline Total & 1 & 7 & & 3 & 0 \\
\hline$\%$ of Assemblage & $1.0 \%$ & $7.0 \%$ & & $3.0 \%$ & - \\
\hline$\%$ of Category & $(10.0 \%)$ & $(65.0 \%)$ & & $(25.0 \%)$ & - \\
\hline \multicolumn{6}{|l|}{ KNAPPED STONE } \\
\hline Total & 2 & 2 & & 0 & 0 \\
\hline$\%$ of Assemblage & $2.0 \%$ & $2.0 \%$ & & - & - \\
\hline$\%$ of Category & $(50.0 \%)$ & $(50.0 \%)$ & & - & - \\
\hline \multicolumn{6}{|l|}{ METAL } \\
\hline Total & 1 & 0 & & 1 & 0 \\
\hline$\%$ of Assemblage & $1.0 \%$ & - & & $1.0 \%$ & - \\
\hline$\%$ of Category & $(50.0 \%)$ & - & , & $(50.0 \%)$ & - \\
\hline $\begin{array}{l}\text { *Includes the entire } \\
\text { material. }\end{array}$ & site asse & lage, excludi & ling & rrestrial & \\
\hline
\end{tabular}

DISCUSSION AND SUMMARY

Evidence of aboriginal occupation is limited and sparsely scattered at site 41WY84. Knapped stone is particularly scarce, indicating limited lithic tool use and manufacture. This situation may be accounted for by the lack of local lithic resources.

Faunal remains suggesting hunting are more abundant. Some show signs of cultural modification in the form of charring. Two of the recovered bone fragments identified as Bison sp. are especially significant due to the limited amount of bison remains reported locally. Of 
particular interest is the bison specimen collected during the survey phase which has a cut edge, indicating animal processing.

Fired clay lumps are the most numerous specimens in the 41wy84 assemblage. One-half of the clay lumps and a minute amount of the charcoal were produced from the relatively intact cultural zone. These materials probably reflect food preparation and other hearth-related activities.

Finally, the presence of metal objects is believed to derive from recent land use. No undisturbed associations between the metal and aboriginal specimens could be established.

\section{COMPARATIVE ANALYSIS}

The results of testing at 41 WY 84 are compared with data recovered from test excavations at two other sites in Willacy County, 41 Wy71 and 41 WY72 (Day 1981:54) (Table 13). When considering relative frequencies, sites 4 lWY71 and 4IWY84 have several similarities -- both lack ground stone and ceramics. Sites 41 WY72 and 41 WY8 4 are similar in that they both lack cores and marine shells.

Unlike site $41 W Y 72$, site 41 WY84 yielded no temporally diagnostic artifacts. Furthermore, 41 WY 84 appears to have a single component while 41 WY71 and 41 WY72 were stratified, undisturbed deposits. Despite these differences, general similarities between the three sites exist. Hunting and gathering adaptations appear to be suggested by the material remains of each site.

The information gathered at these sites is insufficient to make accurate assessments regarding aboriginal seasonality patterns, social group size or temporal range.

\section{ASSESSMENT AND RECOMMENDATIONS}

Test excavations conducted at site 41 WY 84 revealed it to be a highly disturbed, single aboriginal component of probable prehistoric age. Since temporal diagnostics were not recovered and sufficient amounts of material for radiocarbon assay were lacking, more precise temporal placement of the component is not possible.

Because of the apparent lack of intact, significant deposits, it is felt that further work at site 41 WY 84 would be scientifically unproductive at this time. Furthermore, nomination to the National Register of Historic Places is not warranted on the basis of the test results presented in this report. Archeological clearance is therefore recommended for the proposed Willacy County Drainage District No. I Main Floodway Channel alignment. 


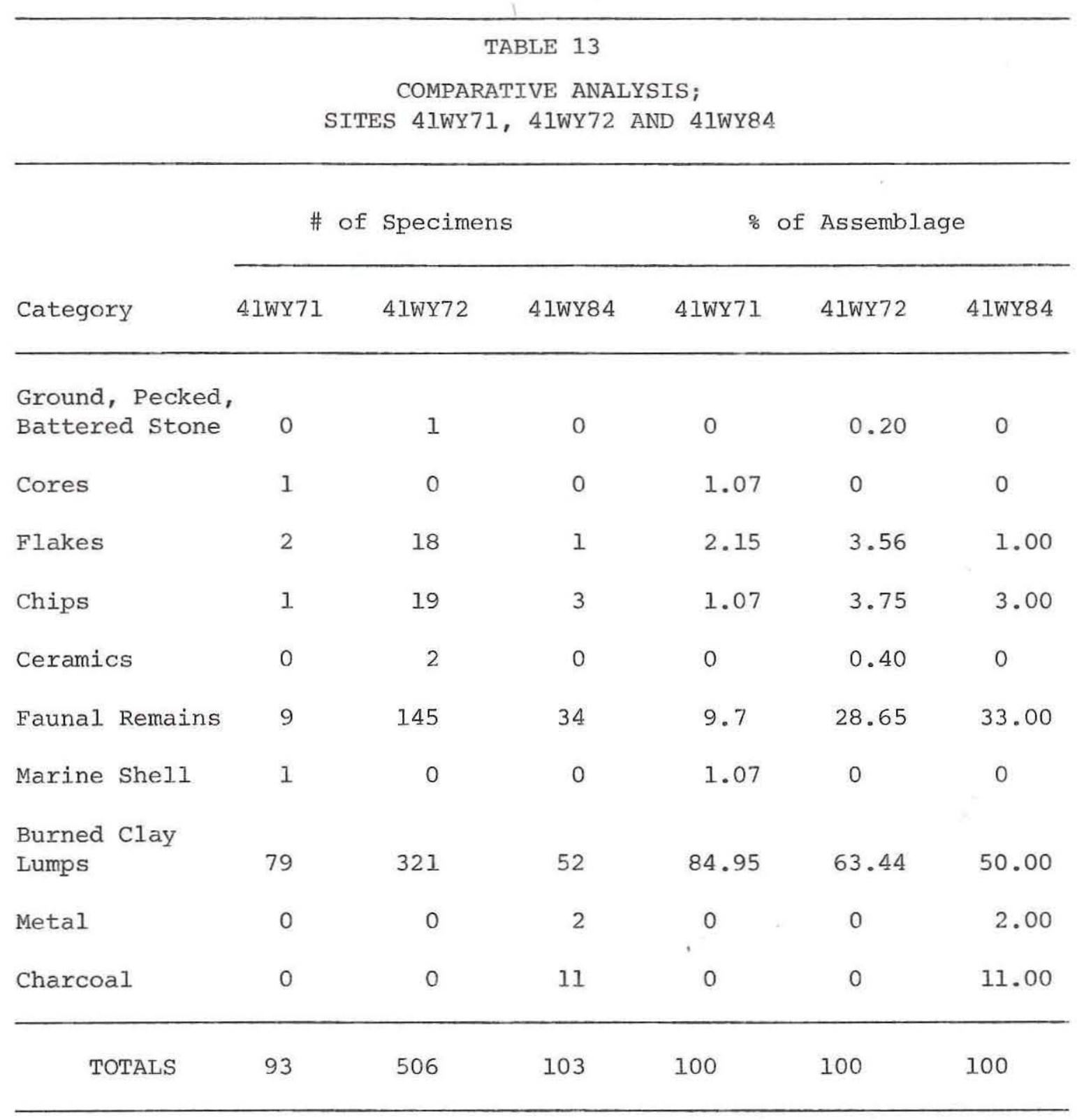


REFERENCES CITED

Bel1, Robert E.

1958 Guide to the identification of certain American Indian projectile points. Special Bulletin No. 1 of the Oklahoma Anthropological Society.

Blair, W. Frank

1950 The biotic provinces of Texas. The Texas Journal of Science $2(1): 93-117$.

Day, D. William

1981 An assessment of archeological sites 41WY71 and 41WY72, Willacy County, Texas. Prewitt and Associates, Inc. Reports of Investigations 17. Austin, Texas.

Day, D. William, Jane Laurens Day and Elton R. Prewitt

1981 Cultural resources surveys and assessments in portions of Hidalgo and Willacy counties, Texas. Prewitt and Associates, Inc. Reports of Investigations 15. Austin, Texas.

Hester, Thomas R.

1981 Tradition and diversity among the prehistoric hunters and gatherers of southern Texas. Plains Anthropologist 26-92: 1.19-126.

Mallouf, Robert J., Barbara J. Baskin and Kay Killen

1977 A predictive assessment of cultural resources in Hidalgo and Willacy counties, Texas, Texas Historical Commission. Office of the State Archeologist Survey Report 23. Austin, Texas.

Munsell Color Co.

1975 Munsell Soil Color Charts. Macbeth Division of Kollmorgen Corporation, Baltimore, Maryland.

Olsen, Stanley J.

1969 Post-cranial skeletal characteristics of Bison and Bos. Papers of the Peabody Museum of Archaeology and Ethnology, Harvard University Vol xXXV, No. 4. Cambridge, Massachusetts.

Prewitt, Elton R.

1974 Preliminary archeological investigations in the Rio Grande Delta of Texas. Bulletin of the Texas Archeological Society $45: 55-65$. 